\title{
Soil Fertility Is a Productive Capital Asset
}

\author{
Michael James Platts' ${ }^{1}$ Yuen Yoong Leong ${ }^{2}$ \\ ${ }^{1}$ Institute for Manufacturing, University of Cambridge, Cambridge, UK \\ ${ }^{2}$ WAYY Consulting, Kuala Lumpur, Malaysia \\ Email:mjp@eng.cam.ac.uk, YYL@thewayy.com
}

How to cite this paper: Platts, M.J. and Leong, Y.Y. (2020) Soil Fertility Is a Productive Capital Asset. Agricultural Sciences, 11, 744-776.

https://doi.org/10.4236/as.2020.118049

Received: June 15, 2020

Accepted: August 28, 2020

Published: August 31, 2020

Copyright $\odot 2020$ by author(s) and Scientific Research Publishing Inc. This work is licensed under the Creative Commons Attribution-NonCommercial International License (CC BY-NC 4.0). http://creativecommons.org/licenses/by-nc/4.0/ (c) (i) (5) Open Access

\begin{abstract}
In recent years, the understanding of human health has progressed considerably, through the study and understanding of the symbiotic role played by the myriad microorganisms that populate the gut and do the digesting, and populate the skin and keep it healthy, and even populate the lining of the lungs and do the same. In plant life, it is the microorganisms in the soil-which "are" the soil's fertility—which fulfil a similar symbiotic role in a healthy plant's life, but as yet this is a subject most visible by its absence from all scientific discussion of good farming practice. The science underlying this understanding is summarised in this paper. Understanding this and nurturing the fertility of impoverished soil by "seeding it" with the appropriate mix of microorganisms is transformational for plant health and productivity. Significant results are indicated from early trial examples of doing this in rice, oil palm and tobacco cultivation in Malaysia.
\end{abstract}

\section{Keywords}

Symbiosis, Soil Fertility, Productive Capital Asset, Soil Microbial Content, Increased Yields, Plant Health, Rice Cultivation, Palm Oil, Tobacco, Fusarium Wilt, Ganoderma

\section{Introduction}

The single organisational principle that all organic life is built on is symbiosis. Organisms exist because they do things for each other, such that they are, together, able to sustain the endlessly repeating cycles of life.

Large moving organisms (animals, birds, insects etc.) are all formed, bodily, around an inner duct through which "food" passes (the digestive tract) that is maintained by the body as a protected and controlled environment for the myriad microorganisms that live symbiotically within it and break down the "food" and transform it into the nutrients that they themselves, and also the surround- 
ing body, can absorb. In humans, the stomach maintains an essentially acidic environment which supports the microorganisms that do the first stages of breaking down the ingested "food", whilst the small intestine maintains an essentially alkaline environment in which a different set of microorganisms prepare all the trace elements etc. that both they and the body need into forms ready to be absorbed by the body through the inner wall of the small intestine. The wall of the large intestine then absorbs water from the duct, leaving the unusable dryer, more solid matter-which in fact largely consists of the dead remains of those myriad organisms that have been doing the work-to be excreted as faeces, which, in turn, form semi-prepared food for the myriad microorganisms living in the soil. The important thing to note is that what we call "food" is not nourishment for the body at all without the transformative work done on it by these microorganisms living symbiotically with us in our gut.

Further than this, ruminant animals have a first digestive stage-the rumen-specially created and maintained to support the initial breakdown of relatively robust plant material. For instance, whereas cows and sheep, which are grazing animals, have a rumen of modest capability, goats, which are browsing animals and take in a far wider variety of foodstuffs, have a far more vigorous rumen, for digesting it. Ruminants form an important part of the whole organic cycle.

It is helpful to have in mind this creation and maintenance of a digestive tract by all large moving organisms, which forage for their food. Plants, which are not moving organisms, cannot forage, and their digestion process is not based on an internal duct where "the environment" is under the control of the organism itself but on an important outward-facing symbiotic relationship between its roots and the surrounding microbial population that lives with it and prepares the nutrients that the plant needs, ready for absorption inwards through the outer wall of the fibrous root system.

On the microbial processing of the mineral elements in soil, it is crucial to highlight the importance of the presence of certain quantities of key minerals in the right ionic form for the microbes to be able to pick them up and be vigorous themselves. As these key elements in the right form are not always present in all soils, adding them with the microbes is an important detail. This is an important detail of what "symbiosis" actually means in practice. All the details have to be present-and in the right form-otherwise the integrated system cannot work. What is visible from the low level of interest taken in how Nature works, is that people will neither think about it nor look for it, so it will pass by unnoticed as a need and unaddressed, i.e. it is for all practical purposes non-existent. It is this blindness towards anything and everything concerning the detail of what constitutes fertility in soil that is the problem we have to address.

It is this microbial population in the surrounding soil which is the soil's "fertility" and which is the focus of this paper. As the plant has only limited ability to create the surrounding fertility it needs to help it develop and maintain its 
own health, the farmer needs to help. To do this well, the farmer needs to understand what constitutes true "fertility" in soil and work to create and maintain it. Anyone who runs a factory understands that it is the maintained productivity of the machinery in the factory that constitutes the productive capital of the company. An essential aspect of farming, far too frequently lacking, is the same understanding that the fertility of the soil is, in exactly the same way, the farmer's productive working capital, and is their largest single asset, requiring carefully focused attention and handsomely repaying steady investment in its development and maintenance.

\section{Soil Fertility}

The soil acts as a processing environment from which the plant receives the nutrients it needs for growth. For the soil to provide an ideal condition for plant growth, three parameters-physical, chemical and biological-must be in ideal balance. Physically, the soil is the region that supports plant life and from which plants obtain mechanical support and many nutrients. Chemically, it contains a multitude of organic substances not found in the underlying strata. Biologically, the soil's environment contains a vast array of bacteria, actinomycetes, fungi, algae and protozoa that carry out the decomposition of organic matter and enable nutrient assimilation by plants.

The soil is made up of five major components (Table 1).

Although the living portion of the soil body constitutes less than $1 \%$ of the total volume, yet it is the essential component for crop production and is the soil's fertility.

The rate of microbial activity depends largely on the organic matter content of the soil and is normally measured in terms of $\mathrm{CO}_{2}$ being released or produced. Under controlled temperatures of between $20^{\circ} \mathrm{C}-30^{\circ} \mathrm{C}$, the rate of $\mathrm{CO}_{2}$ production is commonly from $5-50 \mathrm{mg}$ of $\mathrm{CO}_{2}$ per $\mathrm{kg}$ of soil per day [2]. Microbial respiration changes with temperature. It increases by more than two times for every $10^{\circ} \mathrm{C}$ soil temperatures rise, up to a maximum of $35^{\circ} \mathrm{C}-40^{\circ} \mathrm{C}$, beyond which soil temperature is too high, limiting plant growth, microbial activity and soil respiration [3]. It is the range of microbial productivity that defines the soil's fertility.

As well as being measurable by the $\mathrm{CO}_{2}$ it produces, with the right microphone

Table 1. Five major components of soil [1].

\begin{tabular}{lc}
\multicolumn{1}{c}{ Soil Components } & Percentages \\
\hline (i) Mineral matter (e.g. rocks) & Almost $95 \%$ \\
(ii) Water & \\
(iii) Air & $3 \%-6 \%$ \\
(iv) Organic matter (e.g. leaves and decomposed animals) & $<1 \%$ \\
(v) Living organisms & \\
\hline
\end{tabular}


and amplification, this microbial activity can be heard, and this potentially provides a far more practical in-field way of measuring and monitoring the development and productivity of the soil [4] [5]. Fertile soil "sings as it works".

The $\mathrm{CO}_{2}$ emitted as this energy is expended is not lost from the whole symbiotic cycle-of-life. As the soil emits the $\mathrm{CO}_{2}$ into the air above, it is absorbed by the green leaves of the above-ground vegetation and converted back into carboniferous structural material by photosynthesis using the energy of the sun's rays. The associated hydrogen that has also been released is recycled as $\mathrm{H}_{2} \mathrm{O}$-water-within the plant. Then, when the hydrogen and carbon are re-combined into sugars by the chloroplasts residing symbiotically within the cells of the leaf using the sun's energy, oxygen is released back into the surrounding air by the leaves, to be breathed in by the large moving organisms (e.g. animals) [6]. Here, the oxygen is carried from the lungs to the body's cells by the haemoglobin residing symbiotically in the red blood cells. Once delivered to the cells, it can be re-combined with the hydrogen and carbon of the sugars (which have also been prepared and transported there) as required, to release the energy captured earlier from the sun's rays in the plant leaves, creating $\mathrm{CO}_{2}$ and $\mathrm{H}_{2} \mathrm{O}$ again.

Nature's thoroughness is displayed in the degree of coordinated symbiotic operational detail between organisms of different scales. Small organisms do atomic manipulations at molecular level within the living cells of larger organisms in this circulation of carbon, hydrogen and oxygen. Not a single detail is left unorganised. Everything is balanced within what can be thought of as a continuous figure-of-eight above ground-below ground circulation of the centrally important flow of energy-capturing, storing and releasing material in the cycle of nature that we call life (Figure 1).

The point is not that life symbiotically includes these small, detailed, atomic-level acts of creation. Life has evolved from these small, detailed, atomic-level acts of
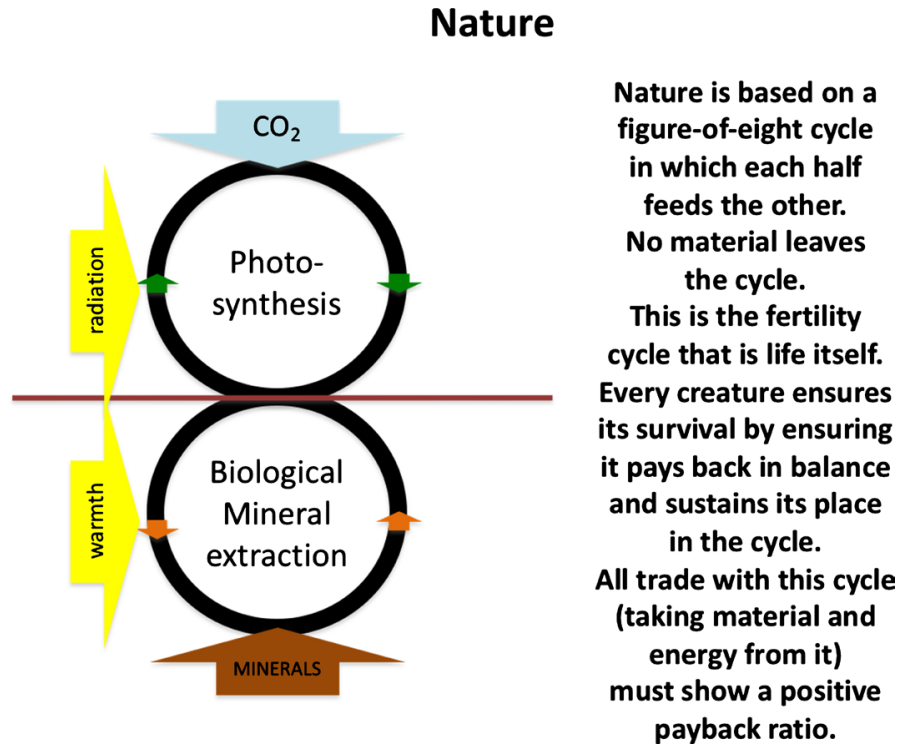

Figure 1. Nature's cycle of life. 
creation, by layer upon layer of further acts of co-ordinated creation over hundreds of millions of years. These "small details" are central to what life actually is. With an eye for this level of detail, it is now possible to look at what some of the microorganisms in the soil are doing.

The next section discusses the macronutrients (nutrients needed in substantial quantities) and micronutrients (nutrients needed in very small amounts) essential for plant growth, and their relationship with microorganisms.

\subsection{Biological Nitrogen Fixation}

Nitrogen is a critical limiting element for plant growth and production. To meet the increasing nitrogen demand in conventional agriculture, synthetic fertilisers have been used extensively in the latter part of the twentieth century, adding to the nitrogen cycle and consequently to surface water and groundwater pollution [7]. The Haber-Bosch process used to produce synthetic fertiliser is energy intensive and fossil fuels are burnt to produce the required energy. This results in carbon dioxide emissions and pollution [8]. Biological nitrogen fixation (BNF) in plants is an essential mechanism for sustainable agriculture and a healthy ecosystem.

Nitrogen is fixed, or combined, in nature as nitric oxide by lightning and ultraviolet rays, but more significant amounts of nitrogen are fixed as ammonia, nitrites, and nitrates by soil microorganisms that transform atmospheric nitrogen into fixed nitrogen (inorganic compounds usable by plants). The latter accounts for more than $90 \%$ of all nitrogen fixation [9].

Biological nitrogen fixation was discovered by Beijerinck in 1901. Two kinds of nitrogen-fixing bacteria are recognised (Table 2).

Environmental factors that govern the rate and magnitude of nitrogen fixation include nutrients, energy source, $\mathrm{pH}$, moisture and temperature.

The quantity and nature of nutrients available, both organic and inorganic, markedly affects nitrogen assimilation. Trace elements such as molybdenum, iron, calcium, magnesium, copper and boron, are critical for the fixation reaction [12] [13].

The availability of energy sources is also a major factor limiting the rate and extent of nitrogen assimilation by heterotrophic populations [14]. The extent of nitrogen gain-which varies considerably-is related to the quantity of carbon source added and the prevailing temperature [15]. From less than $1 \mathrm{mg}$ to about $30 \mathrm{mg}$ nitrogen may be assimilated per gram of carbon source by the soil's productive population.

Table 2. Nitrogen-fixing bacteria [8] [9] [10] [11].

$\begin{array}{cl}\begin{array}{c}\text { Free Living } \\ \text { Bacteria }\end{array} & \begin{array}{c}\text { Cyanobacteria (or blue-green algae) Anabaena and Nostoc and genera such as } \\ \text { Azotobacter, Bacillus, Beijerinckia, Clostridium, Desulfovibrio and Klebsiella. }\end{array} \\ \begin{array}{c}\text { Mutualistic } \\ \text { Bacteria }\end{array} & \begin{array}{l}\text { Rhizobium, associated with leguminous plants, and various Azospirillum } \\ \text { species, associated with cereal grasses. }\end{array}\end{array}$


The prevailing $\mathrm{pH}$ has a profound influence on the abundance of these organisms. For example, Azotobacter is characteristically sensitive to high acid condition [10] [16]. The genus Beijerinckia, on the other hand, does not possess the same acid sensitivity of the Azotobacter, and it develops and fixes nitrogen from pH 3 - 9 [17]. Blue-green algae develop poorly in media more acidic than $\mathrm{pH} 6$ [18].

The rate of nitrogen fixation is also dependent upon moisture and temperature [19]. Gains are insignificant when little water is available, but the rate and magnitude of the fixation increases as moisture becomes abundant. Excessive moisture, however, encourages anaerobiosis that may result in a foul smell [20]. Temperature also has a profound influence on nitrogen metabolism, the ideal range being mesophilic $\left(33^{\circ} \mathrm{C} \pm 5^{\circ} \mathrm{C}\right)$.

\subsection{Microbial Transformation of Phosphorus}

Phosphorus is the second most important macronutrient required by plants to function normally, after nitrogen. Phosphorus deficiencies can reduce plant growth and development. Soil possesses total phosphorus in the form of insoluble organic and inorganic (mineral) compounds, most of them inactive and thus unavailable to plants. Unlike the case for nitrogen, no large atmospheric source of phosphorus can be made biologically available [21] [22].

The chief source of inorganic phosphorus compounds entering the soil is through the vast quantity of vegetation that undergoes decay. Its concentration in plants ranges from $0.05 \%$ to $0.5 \%$ of total plant dry weight [23]. This element is found in several compounds or groups of substances such as phytins, phospholipids, nucleic acids, phosphorylated sugars, coenzymes and related compounds [24].

In the natural environment numerous microorganisms in the soil and rhizosphere are effective at releasing phosphorus from total soil phosphorus through solubilisation and mineralisation [25]. This group of microorganisms are referred to as Phosphorus Solubilising Microorganisms (PSM). Although PSM has been a subject of research for decades, using it to improve crop production at the field level has yet to become a mainstream practice [26]. The inoculation of soil or crop with phosphate solubilising/mineralising microorganisms is a promising strategy for enhancing plant absorption of phosphorus, which will reduce the use of chemical fertilisers that have a negative impact on the environment [27].

A large number of microorganisms including bacteria, fungi, actinomycetes, and algae exhibit phosphorus solubilisation and mineralisation ability (Table 3 ).

Soil fungi have been reported to traverse long distances within the soil more easily than bacteria and may be more important to the solubilisation of inorganic phosphate in soils because they typically produce and secrete more organic acids [41]. Organic acids naturally produced through microbial action immensely enhance the solubilisation and mobilisation process of the element. 
Table 3. Microorganisms that exhibit phosphorus solubilisation and mineralisation ability [42].

\begin{tabular}{ll}
\hline Bacteria & Pseudomonas spp., Agrobacterium spp., Bacillus circulans [28], Azotobacter [29], \\
& Bacillus [30] [31], Burkholderia [32] [33] [34], Enterobacter, Erwinia [35], \\
& Kushneria [36], Paenibacillus [37], Ralstonia, Rhizobium [38], Rhodococcus, \\
& Serratia, Bradyrhizobium, Salmonella, Sinomonas and Thiobacillus [31] [39] \\
Fungi & Achrothcium, Alternaria, Arthrobotrys, Aspergillus, Cephalosporium, \\
& Cladosporium, Curvularia, Cunninghamella, Chaetomium, Fusarium, Glomus, \\
& Helminthosporium, Micromonospora, Mortierella, Myrothecium, Oidiodendron, \\
& Paecilomyces, Penicillium, Phoma, Pichia fermentans, Populospora, Pythium, \\
& Rhizoctonia, Rhizopus, Saccharomyces, Schizosaccharomyces, Schwanniomyces, \\
& Sclerotium, Torula, Trichoderma, and Yarrowia [40] [41] \\
Actinomycetes & 20\% of actinomycetes could solubilise phosphorus, including those in the genera \\
& Actinomyces, Micromonospora, and Streptomyces. [41] \\
& Cyanobacteria [41] \\
Algae &
\end{tabular}

Moisture also assists in the process. It has been confirmed that flooding increases phosphorus availability [43] and this explains why rice cultivated under water often has a lower requirement for phosphorus fertiliser than the same crop grown in dry land agriculture.

\subsection{Microbial Transformation of Potassium}

Potassium is the third major essential plant nutrient for enzyme activation, protein synthesis and photosynthesis. Potassium deficient soils are often acidic, sandy, saline, and waterlogged [44]. Potassium deficiency usually results in both a decrease in crop yields, quality and resistance to pathogens and insect pests [45] [46].

Total potassium content in soil commonly ranges between $0.5 \%-2.5 \%$, depending on soil type and climatic conditions, but usually $90 \%-98 \%$ of that total potassium is in the form of a mineral, thus not available for plant use [47]. Hence, potassium is one of the macronutrients supplied in inorganic fertilisers. Certain microorganisms known as potassium-solubilising microorganisms (KSM) can use biological processes to solubilise different kinds of potassium compounds and make their potassium ions available for plant growth. [48] [49] [50].

KSM can dissolve silicate minerals and release potassium through the production of inorganic and organic acids, acidolysis, polysaccharides, complexolysis, chelation, and exchange reactions [48]. Typical of this group of microorganisms are the fungal species of Aspergillus, Mucor and Penicillum [51].

Bacteria such as Acidothiobacillus ferrooxidans, Paenibacillus spp., Bacillus mucilaginosus, $B$. edaphicus, and $B$. circulans have the capacity to solubilise potassium minerals such as biotite, feldspar, illite, muscovite, orthoclase, and mica. KSM from different environments (e.g. ex-mining land vs. agricultural land) have different abilities to solubilise these potassium minerals [52].

\subsection{Microbial Transformation of the Micronutrients}

Many elements undergo microbiologically induced transformation. In addition 
to the elements already cited, there is evidence for direct and indirect biological alteration in the availability, solubility or oxidation state of boron, chlorine, copper, iron, manganese, molybdenum, nickel, and zinc [53] [54]. This section uses three examples to illustrate the relationship between soil microbes and plant uptake of micronutrients.

(i) Manganese is required by plants in tiny amounts to grow and mature properly. Otherwise, plant growth will be adversely affected as if they lacked the major elements [55]. Manganese in soils is present in three oxidation states: $\mathrm{Mn}^{+2}, \mathrm{Mn}^{+3}$ and $\mathrm{Mn}^{+4}$ of which $\mathrm{Mn}^{+2}$ (i.e. a reduced form) is the primary form in which manganese is absorbed by plants [56]. Availability of manganese in the soil can be gauged using the ratio of soil oxidising and reducing manganese bacteria [57]. In the rhizosphere of manganese-efficient plants, the number of manganese reducing microbes is higher than the oxidising ones. The reverse is true in the rizosphere of inefficient genotypes [58] [59].

(ii) Zinc is an imperative micronutrient required in small concentrations (5 $100 \mathrm{mg} \cdot \mathrm{kg}^{-1}$ ) in tissues for optimum plant growth [60] [61]. The major reason for the widespread occurrence of zinc deficiency problems in crop plants is attributed to low solubility of zinc in soils rather than a low total amount of zinc [62]. Customary application of inorganic zinc only partially caters for the plant need because $96 \%$ - 99\% of applied zinc is converted into different insoluble forms depending on the soil types and physicochemical reactions within seven days of application [63] [64]. Microbes are a potential alternative that can cater for the plant zinc requirement by solubilising the complex zinc in the soil. Several genera of rhizobacteria belonging to Pseudomonas spp. and Bacillus spp. are reported to solubilise zinc. Microbes solubilise the metal forms by acidification, production of siderophores, protons, chelated ligands, and oxido-reductive systems on cell membranes [65] [66] [67] [68].

(iii) Copper is essential for activating some enzymes in plants, photosynthesis, plant respiration and plant metabolism of carbohydrates and proteins [69]. Copper level may also be affected by the metabolism of microflora. For example, the concentration of soluble copper decreases during decomposition of crop residues [70]. Two schools of thought exist on how copper is liberated in the soil [71] [72]:

- One holds that the oxidation of the sulphide or ferrous ions in the ores by Acidithiobacillus ferrooxidans (reclassified in 2000, previous name: Thiobacillus ferrooxidans) yields sulphuric acids or ferric ions that then react with materials like the main copper mineral chalcopyrite $\left(\mathrm{CuFeS}_{2}\right)$ to solubilise the copper by purely non-enzymatic means;

- Proponents of the second view of copper release from sulphides argue that Acidithiobacillus ferrooxidans is capable of bringing about an enzymatic oxidation of cuprous to cupric ions, a process that is believed to provide energy for microbial growth.

It may be noted that, in the above discussion, numerous effects are already 
well established by scientific study. Others have the nature of insightful postulations coming from practical experience, being probably true and worth using as pragmatic guidance in the exploratory development of good farming practice, whilst suggesting areas for the establishment of focused supportive scientific investigation. This is a whole field of work, involving both theory and practice, worthy of serious development.

\section{Developing a Microbial Soil Ameliorant}

The very wide range of fertility found in soil, and the known experience that constant removal of organic matter from the cycle (such as the removal of empty fruit bunches from oil palm plantations) and the constant application of inorganic fertiliser reduces the fertility, raises two questions:

1) Why is soil fertility not both measured and recorded and treated as valuable capital?

2) What helps develop soil fertility and would be a worthwhile target for investment?

Some work has been done in this latter direction and experience is now beginning to demonstrate the value of such targeted investment work.

Over a nine-year period of trial and development in Malaysia, adjustments were made for the microbes to function effectively on raw materials which were high in cellulose, chitin and lignin. This unique super-strain mixture was formulated to meet all the requirements of highly effective fermentation/transformation microbes, which not only benefited the soil but also suppressed the growth of harmful microbes, thus protecting the crop from diseases. The most striking example of this was freeing oil palms from the fungus Ganoderma. OrganiGro Organic Soil Ameliorant (referred to as OrganiGro hereafter) was the final product of the decomposition process of spent sugar molasses, organic silica and Bio-PLUS Activator (BPA). BPA is a scientifically blended catalyst of primary nutrients, 23 types of microorganisms, chelated trace elements, enzymes, growth-promotants, enhancers, and functional compounds mixed together with rice bran, fish meal, soy meal copra meal, and single cell proteins. The content of OrganiGro is shown below. OrganiGro is an example of a good organic soil ameliorant that worked. All results of OrganiGro that are showcased in this paper could be achieved with equivalent organic soil ameliorants with microbial content optimised for respective organic raw materials.

\section{Macro Elements, Micro Elements \& Silica}

$\begin{array}{ll}\text { 1. Nitrogen } & 2.5 \% \\ \text { 2. Phosphorus } & 2.0 \% \\ \text { 3. Potassium } & 2.5 \% \\ \text { 4. Magnesium } & 0.5 \% \\ \text { 5. Calcium } & 4.5 \% \\ \text { 6. Sulphur } & 0.27 \% \\ \text { 7. Zinc } & 0.0048 \%\end{array}$




$\begin{array}{ll}\text { 8. Copper } & 0.0036 \% \\ \text { 9. Manganese } & 0.023 \% \\ \text { 10. Iron } & 0.25 \% \\ \text { 11. Silica } & 9.0 \%\end{array}$

Trace Minerals

Molybdenum, magnesium, manganese, sodium, cobalt, iron, chlorine, silicon, boron, aluminium, selenium

\section{Enzymes}

Cellulase, invertase, lactase, amylase, urease, protease, lipase

\section{Functional Compounds}

Growth promoting substances, vitamins, keto acids, organic acids, acetic, butyric, formic, oleic, stearic, amino acids, lysine, methionine, trytophane, cystine

\section{Others}

Chelating agent, emulsifier, surfactant, stabiliser, sticker

$\begin{array}{ll}\text { Moisture content } & 19.4 \% \\ \mathrm{pH} & 7.5\end{array}$

\section{Microbial Content}

The following microbial mixture was inoculated with twelve improved strains of fungi, which were naturally occurring, and were isolated and cultured on an organic substrate nutritionally fortified with essential nutrients, substances and compounds to enhance microbial growth and proliferation. The twelve improved strains of fungi were not mutated or bio-engineered. Of the 23 microbes identified below, some were available off the shelf, some were cultivated by the BPA manufacturer.

\section{A. Bacteria for Decomposition \& Transformation}

1) Cellumonas fabia

2) Bacillus stearothermophilus

3) Lactobacillus casei

4) Methanobacterium forminicum

5) Methanobacterium ruminantium

6) Thiobacillus oxidans

7) Acidithiobacillus ferrooxidans

8) Bacillus licenformis

9) Bacillus polymexa

10) Bacillus subtilis

\section{B. Actinomycetes}

11) Streptomyces thermophillus

12) Thermoactinomyces vulgaris

13) Thermospora curvata

\section{Nitrogen Fixing Bacteria}

14) Azotobacter vinelandii

15) Nitrosomonas europeae

16) Nitrobacter winogradskyi 


\section{7) Rhizobium japonicum}

\section{Fungi for Decomposition and Transformation}

18) Sacharomyces cerevisiae

19) Humicola insolens

20) Mycorrhiza (Rhizoctonia)

21) Penicillum notatum

22) Aspergillus niger

23) Aspergillus oryzae

Out of the twelve improved strain of fungi, six were no longer present after the composting process was completed. They were included to jumpstart the composting process and spike the temperature quickly to take care of the chitin and lignin in the rice husk. After four to five rounds of turning the pile, they died off. These six un-named fungi strains were the BPA manufacturer's trade secret. The BPA manufacturer gave different microbial configurations depending on the species and raw material used.

The biological decomposition was initially brought about by the combined microbial fermentation of anaerobes such as strains of thermophilic fungi and high temperature tolerant organisms. In order to accelerate the decomposition process, cellulosic enzymes were incorporated into the microbial compound.

The six surviving un-named fungi mentioned above would continue to multiply for as long as a food source was available. Eventually, these fungi would also die, decay, and release nutrients to the pile, which plants could use for growth.

\section{Experience of Using OrganiGro Organic Soil Ameliorant}

A laboratory-based scientific paper would conventionally contain a section showing graphs and tables of numerical results related to measurements of the soil fertility as the subject of interest. It is not conventional farming practice, however, to measure anything in the soil, or indeed measure much at all. What normally stands instead is photographic evidence and explanatory comments focusing on significant results, such as improved crop yields, better plant growth and increased stress and disease resistance. This is presented here, including, in some cases, comments about particular nutritional deficiencies in particular soils being remedied along with the soil amelioration process. The results are substantial, suggesting that far wider experiments need to be undertaken, and should be underpinned by long term thorough scientific study.

In the wider context of studies on climate change, it is well known that increasing fertility of the soil is one of the major carbon sequestration processes that mankind should be focusing on and developing. There is evidence here of significant increases in soil fertility, being achieved both easily and quickly, but there is no numerical data being recorded in these experiments, of what is happening within the soil itself. There is scientific work here crying out to be done.

In pragmatic development trials such as those undertaken so far in Malaysia, numerical data is sparse. However, the "knowing eye" of an experienced practi- 
tioner "sees" a lot and their observational comments, which constitute most of this section of this paper, are not empty comments. On the one hand, they highlight "the tell-tales" that an experienced practitioner looks for and takes as their guide. On the other, they highlight areas in which scientists might focus their attention to create measured data in larger scale testing. The overall effects seen across many different small scale trials can be summarised in five observations:

1) The silica present in OrganiGro helped to increase the yield of cereals. It increased cell turgidity in the stems, enabling the plant to bear more grains with a minimum of lodging;

2) Plants using OrganiGro were more resistant to pests and diseases. This reduced the need for pesticides and fungicides, which saved costs and conserved the environment;

3) The cation exchange capacity of soil was increased, thus enabling the plant to absorb more nutrients;

4) Plants and cereals planted with OrganiGro were more resistant to biotic stresses. The soil physical, chemical and biological structures were repaired and soil $\mathrm{pH}$ was increased;

5) The restructuring of soil using OrganiGro in the long run increased soil fertility. This helped to reduce most chemical inputs, resulting in a healthier environment.

The main consideration of the manufacturers when they decided to embark on this creative journey of developing a potent soil ameliorant based on selected super-strain microbes appropriately supported by their feed, was the way agriculture was practised in Malaysia:

- Crop rotation was not the norm and the rate of chemical fertiliser usage was high and alarming, and the dosage was increasing as time went on;

- Traditional farmers were using fertilisers and pesticides off the shelf without proper guidance. Awareness of the need to reduce these chemical inputs for health considerations in the long run was also lacking;

- Agronomists in research centres belonging to public listed plantation companies were reluctant to venture outside of their comfort zones to suggest unconventional ideas, for fear of loss and failure. They were not comfortable with the idea of holistic agriculture. As a result, their recommendations for treatments for their commodity crop problems tend to be symptomatic and standard operating procedure-like.

The ameliorant manufacturers spent considerable time, effort and resources to educate the public listed plantation companies, and government agriculture research agencies on the ameliorant concept, which was quite alien at that time. The concept of treating the soil rather than feeding the plant directly is known to all agriculture practitioners in the government and private sectors. However, they all had difficulty in assimilating it into their working culture. This could be due to the time taken for significant results to be seen in organic agriculture. Should they be transferred to another division before the completion of their project, their re- 
placement might declare the uncompleted project a failure, then quickly apply a chemical fertiliser that would make the crop look good within a short period of time, and get a commendation for successfully reviving a failed project.

Food safety and food security issues have received increased attention lately due to the worldwide pandemic. The primary requirement for food safety is actually soil treatment with microbes because that can reduce or eliminate the use of pesticides, especially the systemic type [73], which are one of the main contributors to harmful chemicals entering our body. In any country where fertile agriculture land is a constraint, a healthy and balanced soil will increase crop yield without having to cut more forest for agriculture. Increasing yield by this method is far better because natural principles like symbiosis are honoured and biodiversity is conserved.

NPK ratio is the percentage a product contains by mass of nitrogen $(\mathrm{N})$, phosphorus $(\mathrm{P})$ and potassium $(\mathrm{K})$. The problem faced by the manufacturers in the early stage development of the ameliorant was the low N:P:K content of 2.5:2.0:2.5 which, understandably, was criticised by practising agriculturalists as being too low to feed a plant throughout the year. This would not be noticeable in the first few years due to presence of much bonded minerals in the soil from fertilisers applied in earlier years. When the microbes (sometimes incorrectly referred to as miners) ran out of bonded minerals that they could transform into elements assimilable by plants, a small amount of fertiliser could be added. An improved and well-conditioned soil would need less fertiliser to produce a high yield. Beyond that, the silica that was present in the ameliorant increased the density of trichomes or small hairs on the leaves [74]. This increased leaf hardness would deter pests because their lower mandibles could be damaged [75]. Health, in a plant, is achieved by ensuring that innumerable microscopic health-giving and health-protecting details of this kind can be developed and maintained by the plant throughout its lifetime.

Eight case studies in the rice, palm and tobacco industries are presented in Table 4.

\subsection{OrganiGro's Applications in the Rice Industry}

\section{Case Study 1: Rice Fields in Kedah and Sabah}

The small rice trials undertaken were a good indicator of the effectiveness of an organic soil ameliorant. A short planting cycle and a direct measure of yield were helpful for data collection. Saad Marzuki from Kampong Selarong Lalang Alor Star Kedah easily increased rice yield from 6.00 tonnes per hectare to 10.30 tonnes per hectare per season after using the soil ameliorant for two seasons (Figure 2). The rice plant stalks in the upper right section of Figure 2 had OrganiGro, and those in the lower left section did not. It is visible that the OrganiGro strengthened plants produced longer panicles and heavier grains. Similarly, Charles Jonioh and son Christer in Sabah increased rice yield from 3.50 tonnes per hectare to 10.04 tonnes per hectare by using the soil ameliorant. 
Table 4. Case studies.

\begin{tabular}{ll}
\hline Case Studies & Locations and Problems \\
\hline Rice & Rice fields in Kedah and Sabah: low yield \\
Palm & \\
2 & Guthrie Siliau, Negeri Sembilan: hardpan, abiotic stress \\
3 & RISDA Benut Plantation, Johor: ganoderma infestation \\
4 & RISDA Raub, Pahang: poor growth of newly transplanted palms on poor \\
5 & lateritic soil; pest infestation; nursery improvement \\
6 & Plantation at Bruit Island, Sibu, Sarawak: extreme peat soil conditions \\
Tobacco & Private plantation in Niah, Sarawak: problematic young palms \\
7 & \\
8 & Pantai Irama, Kelantan: Fusarium wilt
\end{tabular}

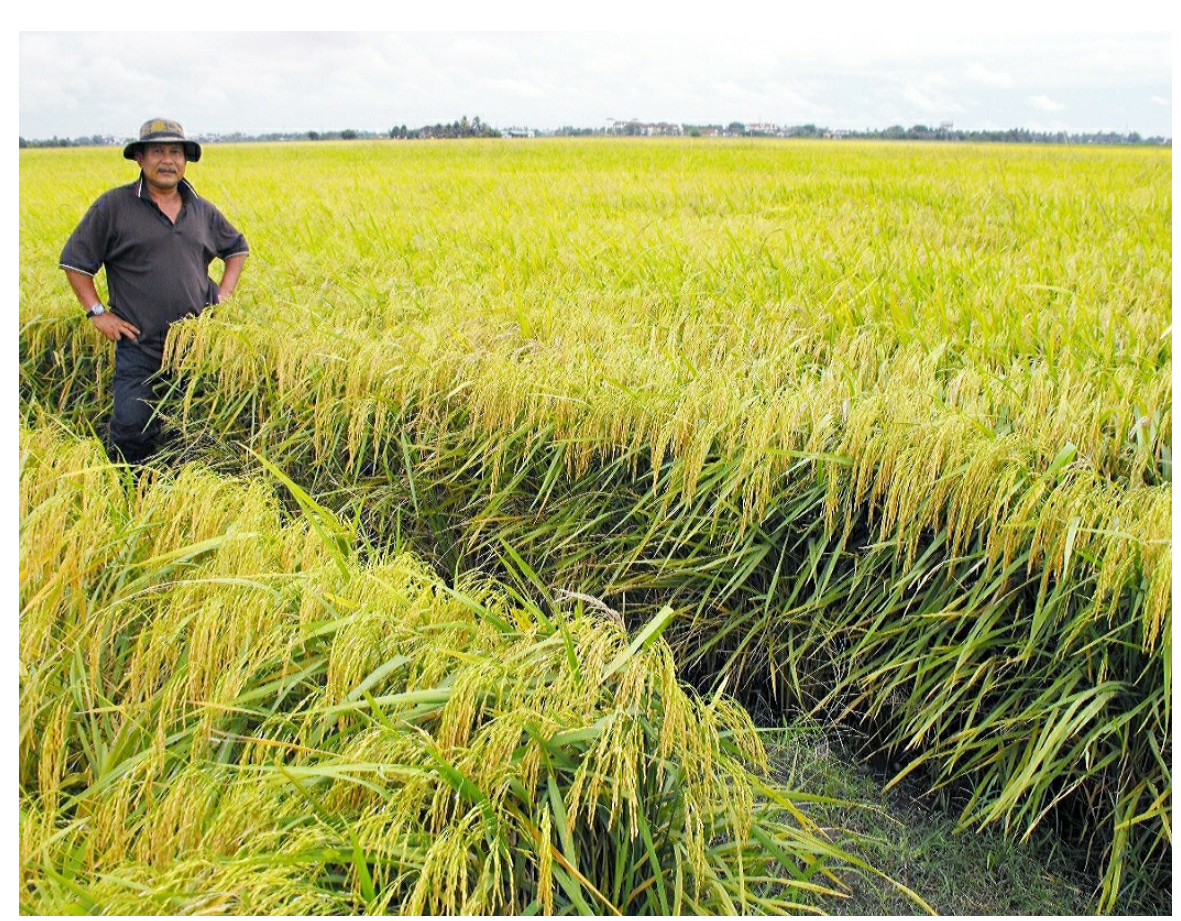

Figure 2. Saad Marzuki's yield was more than 10.00 tonnes per hectare. Average yield in Kedah was only 4.50 tonnes per hectare.

OrganiGro encouraged the growth of paddy roots and rootlets, which enabled the plant to absorb and retain water more effectively. Figure 3 shows OrganiGro treated paddy that still grew well even when more than two weeks of dry weather had caused the land to crack. This gave farmers a longer time window for harvesting.

Six comments summarised what was experienced in rice cultivation:

1) The tillering rate was increased. Farmers saved costs in terms of supply and 


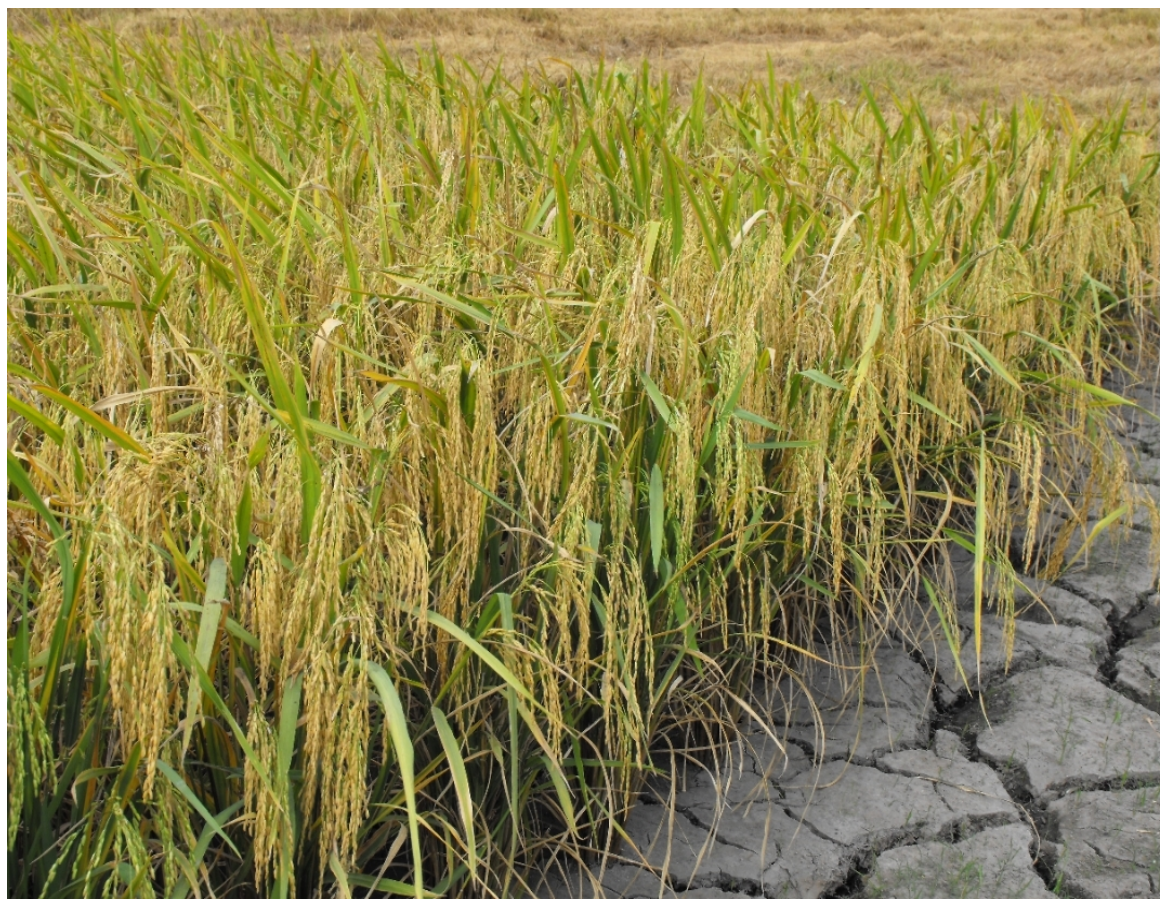

Figure 3. Paddy was still growing well even when more than two weeks of dryness had caused the land to crack.

reducing the seeding rate per hectare;

2) Restructuring of soil improved the uptake of inorganic fertiliser;

3) Wastages of inorganic fertiliser through leaching, volatilisation and mineralisation were reduced. Cereals received more nutrients for better growth;

4) Silica strengthened the rice plant stalks and the plants reacted favourably by producing longer panicles and heavier grains. This contributed to increase in yield;

5) Besides the stalks, the cereal leaves were also strengthened. The flag leaves were more turgid and upright. This assisted better penetration of sunlight to the plant's base, chasing away pests. Hardened leaves also repelled caterpillars and other foliar feeders. This was beneficial for farmers in terms of pest control;

6) The organic component of OrganiGro and the microbes acting on the decaying rice stalks in the field created a more conducive environment for rice plants to grow better roots and rootlets, which enabled the plants to absorb and retain water more effectively, thus becoming more drought resilient.

The rates of usage of OrganiGro were:

- OrganiGro was used only once every planting season as soil treatment;

- It was not a total substitution for inorganic fertiliser and was used in tandem with inorganic fertiliser;

- It could be applied by mixing together with inorganic fertiliser;

- Applied once between the $15^{\text {th }}$ and $30^{\text {th }}$ day after seeding;

- A bag of OrganiGro weighed $25 \mathrm{~kg}$. The recommended rate for cereals under 
flooding condition were:

i) $11.55 \mathrm{~kg}$ per mou (Chinese land area)

ii) 3 bags $(75 \mathrm{~kg})$ per acre or

iii) 7 bags $(175 \mathrm{~kg})$ per hectare

\subsection{OrganiGro's Applications in the Oil Palm Industry}

The trials undertaken in the oil palm industry demonstrated a number of effects and wider introductory comments about the importance of soil fertility are appropriate, as this is such a major industry in Malaysia.

It is the accepted fact that mono-cropping and continued tillage of the soil will eventually lead to "dead soil syndrome". In most developing countries, over-usage of chemical fertilisers and pesticides is more often than not the main culprit.

Not all of the chemical fertilisers applied will benefit the plant. Most of it will be leached into the waterways and eventually pollute human water sources. Some of it will be bonded with other available elements in the soil producing compounds which cannot be assimilated by the plant. This salt compound will increase soil acidity, which will lead to the soil holding on to the nutrients. Thus, there will be an abundance of fertiliser in the soil but not in the plant.

An accepted solution to this problem is by restructuring the soil using organic fertilisers. Organic fertilisers will increase the soil cation exchange capacity and promote better uptake of nutrients. However, the amount of organic fertiliser needed to do the job is high. Technologically speaking, a more effective and economical way is by using a soil ameliorant such as OrganiGro which will yield the same result, but at a lower rate of application.

Apart from using microbes to restructure the soil and break the bonds of the salt compounds, silica is also another element needed to increase plants' resistance to biotic and abiotic stresses. The increased availability of silica with a soil ameliorant allows a reduction of pesticide usage and contributes to sustainable agriculture strongly, both financially and environmentally. Plants in good health do not need medicine.

Case Study 2: Guthrie Siliau, Negeri Sembilan

Guthrie Siliau was in the midst of replanting 200 acres of oil palm when the OrganiGro team visited in August 2003 (Figure 4).

By using OrganiGro in the planting hole, they were able to achieve high quality palms, as demonstrated in the picture (Figure 5).

Figure 6 shows healthy 4-month old palms planted on hardpan.

Figure 7 shows a young palm submerged under water for one month. Silica in OrganiGro protected the palm from abiotic stress, i.e. the palm survived this ordeal without suffocating. Note the voluntary oil palms in the picture were already yellowing. The palms grown in soil treated with OrganiGro managed to retain their green colour even after one month. 


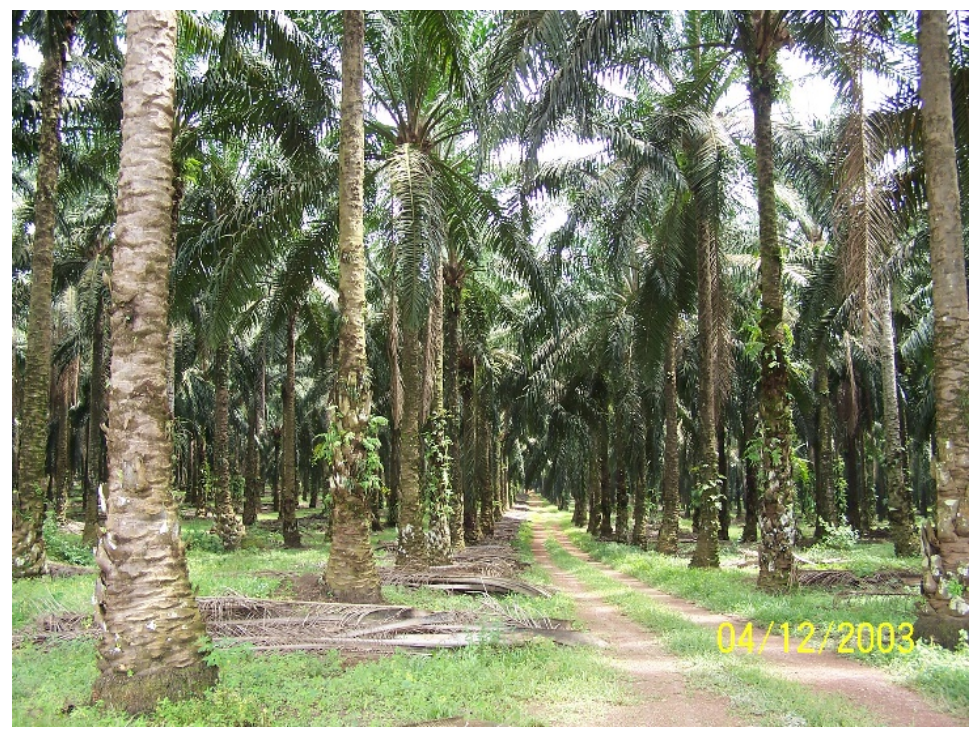

Figure 4. Guthrie Siliau's oil palm estate that was due for replanting in 2003.

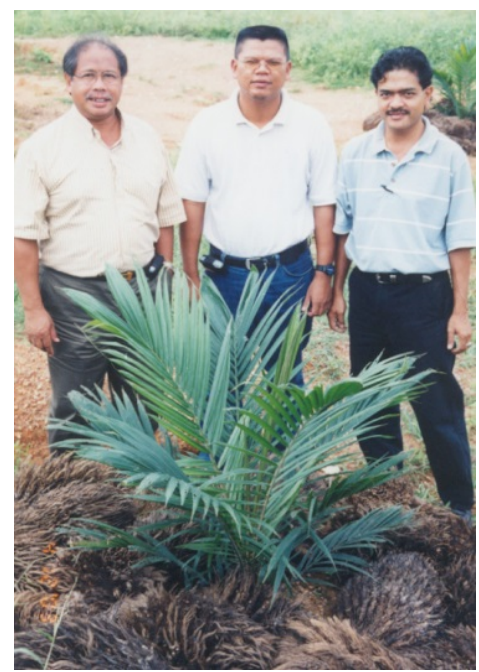

Figure 5. A young palm tree growing well in a planting hole enhanced with OrganiGro.

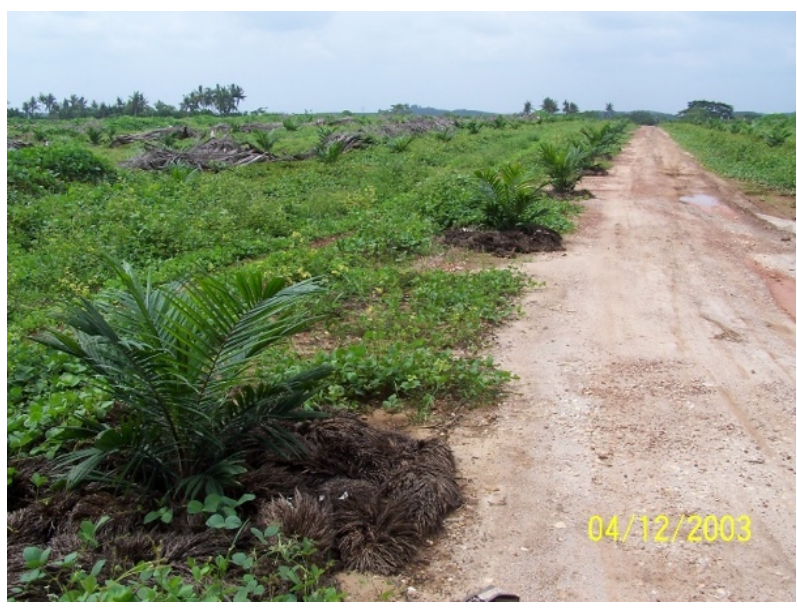

Figure 6. Young palms planted on hardpan grew well when treated with OrganiGro. 


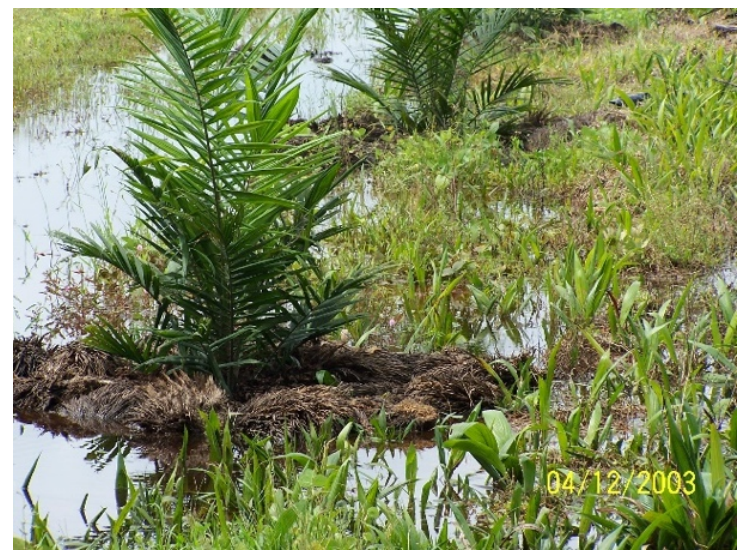

Figure 7. Young palms treated with OrganiGro grew well despite being subjected to abiotic stress.

\section{Case Study 3: RISDA Benut Plantation, Johor-Ganoderma infested} plantation

OrganiGro was applied to some of the young palms (Figure 8 and Figure 9) and a massive difference was observed between them and the control (Figure 10). Imbalances in nutrient uptake, especially in the early stage, stunted the palm
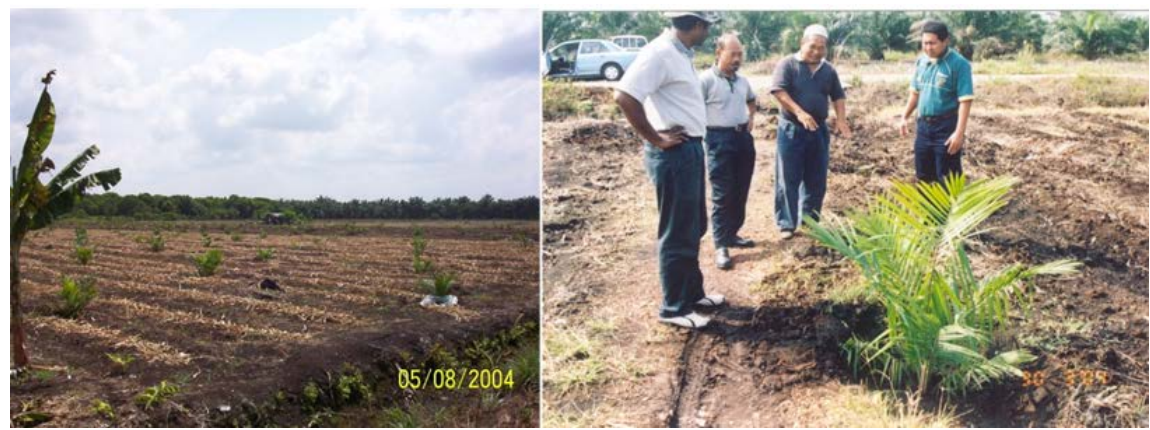

Figure 8. This oil palm plantation was developed on peat land. Palms had poor growth due to insufficient copper, zinc and Ganoderma attack.

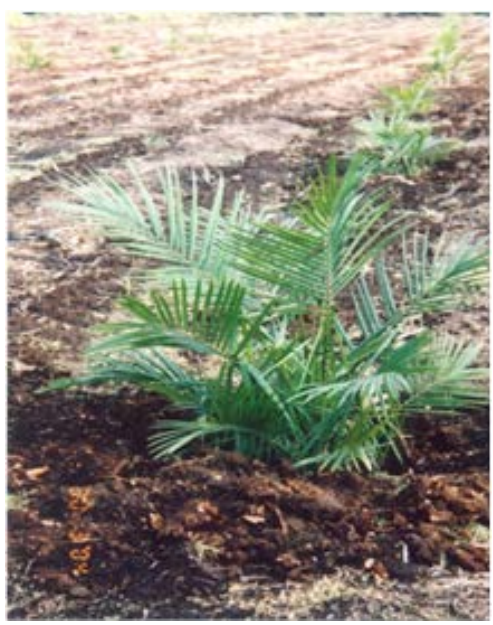

Figure 9. OrganiGro applied. 
and caused leaves to yellow. The efficacy of the microbial combination in OrganiGro in countering Ganoderma infection continued to be observed in later stages of palm growth (Figure 11 and Figure 12).

After seven years, the OrganiGro team revisited the Parit Seraya RISDA Benut Plantation to find the plot treated with OrganiGro still in a healthy state with good yield and having no sign of Ganoderma attack as demonstrated in Figure 13.

The area surrounding the plot in Figure 13 was heavily infected with Ganoderma as shown in Figure 14.

\section{Case Study 4: RISDA Raub, Pahang}

The OrganiGro team visited RISDA Raub's plantation in Ulu Jelu to listen to a manager's briefing on the poor growth of newly transplanted palms on poor lateritic soil (Figure 15).

The picture on the left in Figure 16 shows a stunted and poorly developed

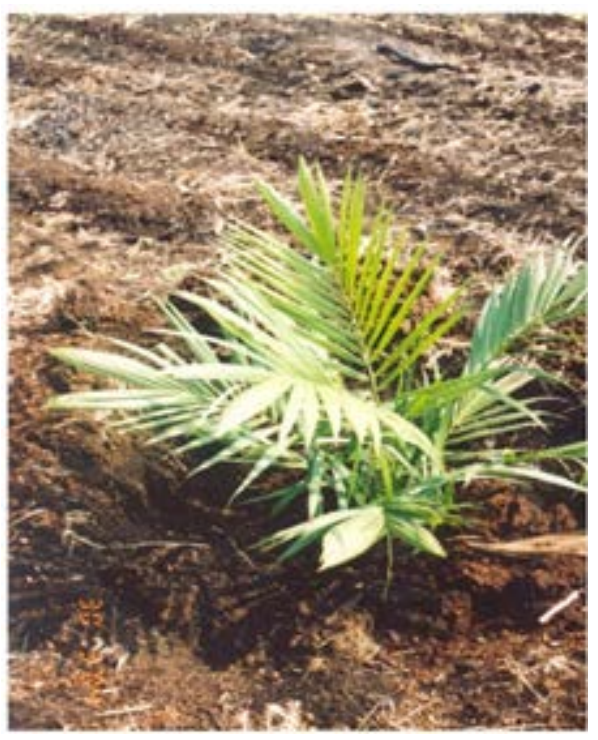

Figure 10. Without OrganiGro (control).

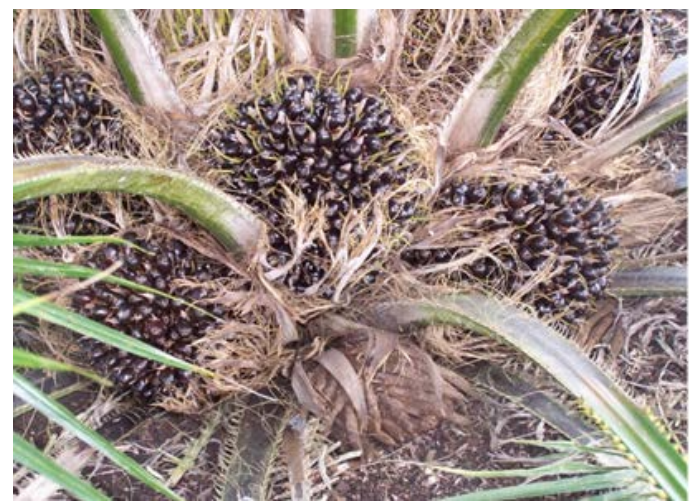

Figure 11. Early fruiting was observed in young palms after eighteen months. OrganiGro $(500 \mathrm{~g})$ and rock phosphate $(300 \mathrm{~g})$ were applied when the palm was transplanted from the nursery to the estate. 


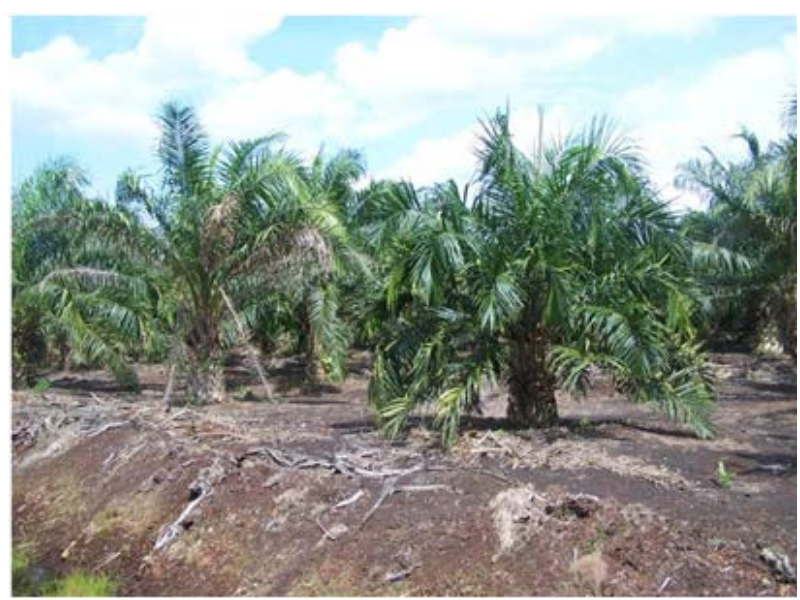

Figure 12. The palms in this estate were infected by Ganoderma. The one in the forefront recovered well after receiving OrganiGro at an early stage of the infection. The palms in the background did not receive OrganiGro, and were wilting as the Ganoderma infection spread.
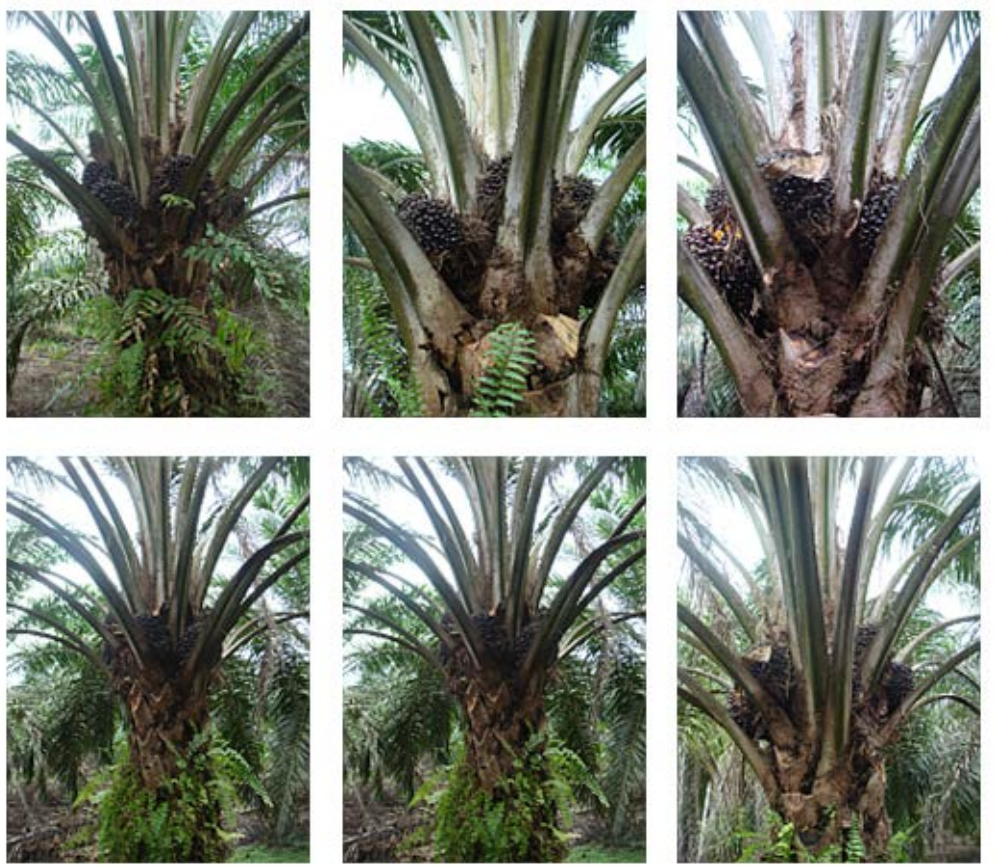

Figure 13. Ganoderma infested plot treated with OrganiGro seven years earlier.
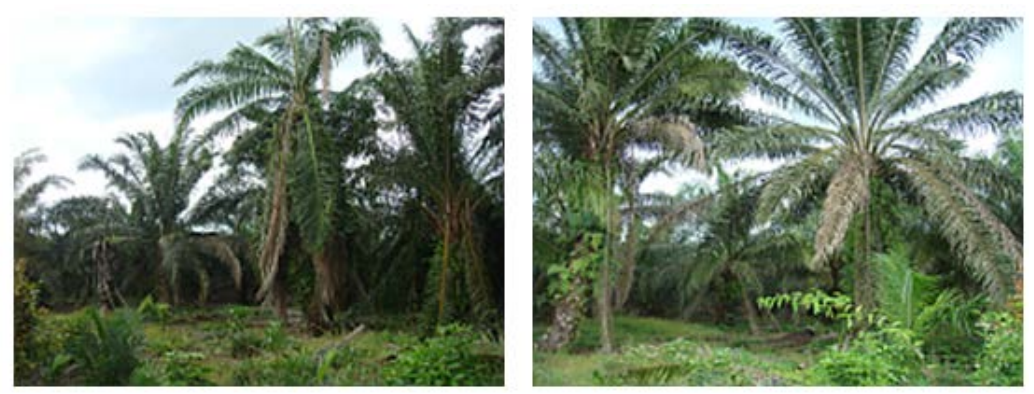

Figure 14. Surrounding area that was heavily infested with Ganoderma. 


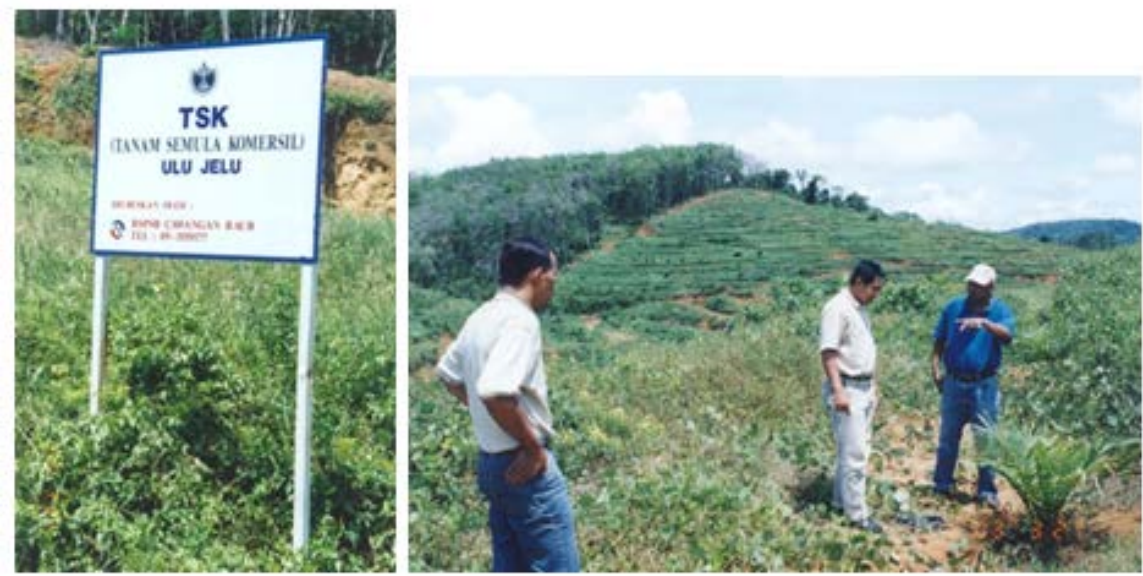

Figure 15. Visit to RISDA Raub's plantation in Ulu Jelu.

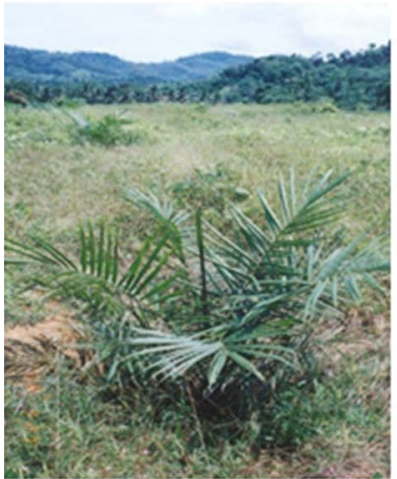

Before

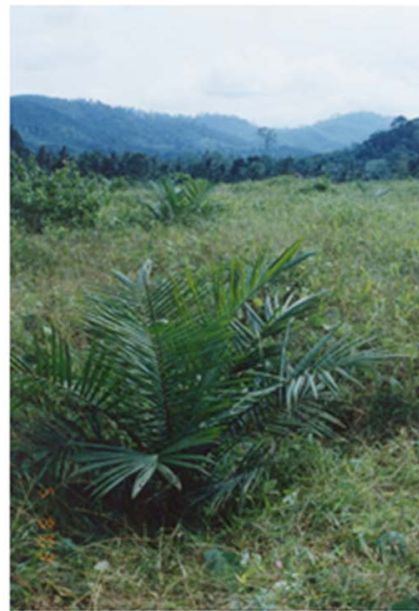

After

Figure 16. Before and after states of a newly transplanted palm treated with OrganiGro.

palm that was newly transplanted. The picture on the right shows the results of two weeks of treatment with OrganiGro. Visible improvements could be seen in leaf coloration and health appearance of the palm.

The seedling on the left in Figure 17 was heavily infected by pests and the leaves were yellow. A combination of silica and beneficial microbes transformed it into a more vibrant plant (right).

Vast differences were observed in young seedlings in a nursery that used OrganiGro and those that did not (Figure 18).

Case Study 5: Extreme Peat Soil Conditions in a Plantation on Bruit Island, Sibu, Sarawak

The palms shown in Figure 19 demonstrate the difference between treated palms (right) which have erect leaves, allowing them to harvest more sunlight, and the control (left) which have droopy leaves mutually overlapping each other. This is the positive effect of having silica in OrganiGro.

Uneven distribution of nutrient and deficiency of nitrogen, copper and zinc in 


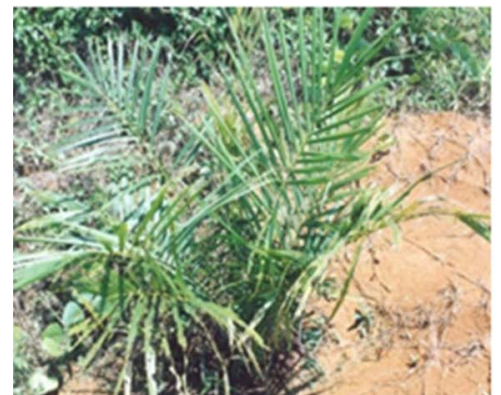

Before

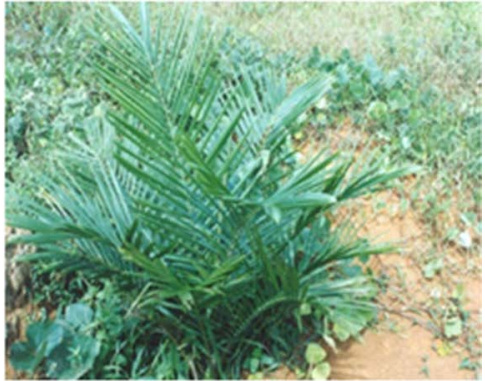

After

Figure 17. OrganiGro's impact on a seedling that was heavily infected by pests.
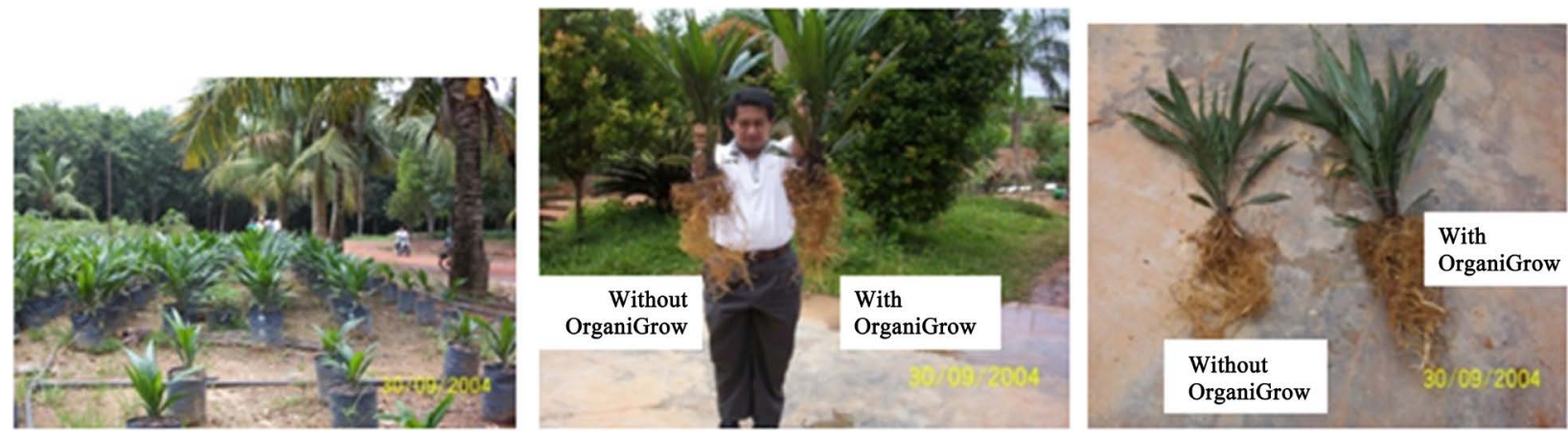

Figure 18. Seedlings in nursery.

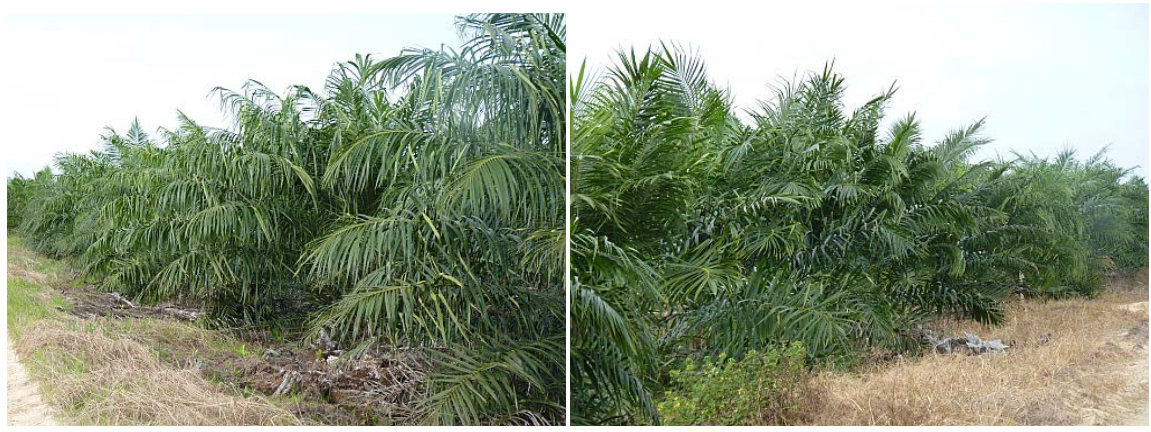

Figure 19. Difference between palms with (right) and without (left) OrganiGro treatment.

the control field in the right segment of Figure 20 was in contrast with the green and even growth on the block treated with OrganiGro on the left of the picture.

The need to ameliorate the soil with OrganiGro was compounded by the proximity of the plantation to the sea, which rendered it susceptible to saline poisoning. The soil was also highly peat. Without ameliorating the soil, planters would be losing $30 \%$ of their first yield and subsequently losing $20 \%$ yield per annum.

Case Study 6: Problematic Young Palms in a Private Plantation in Niah, Sarawak

Figure 21 shows yellowing palms in a plantation (pictures on the left) and the same palms (pictures on the right) one month after OrganiGro treatment. Treated palms were restored to a luscious green in contrast to yellowing palms, 


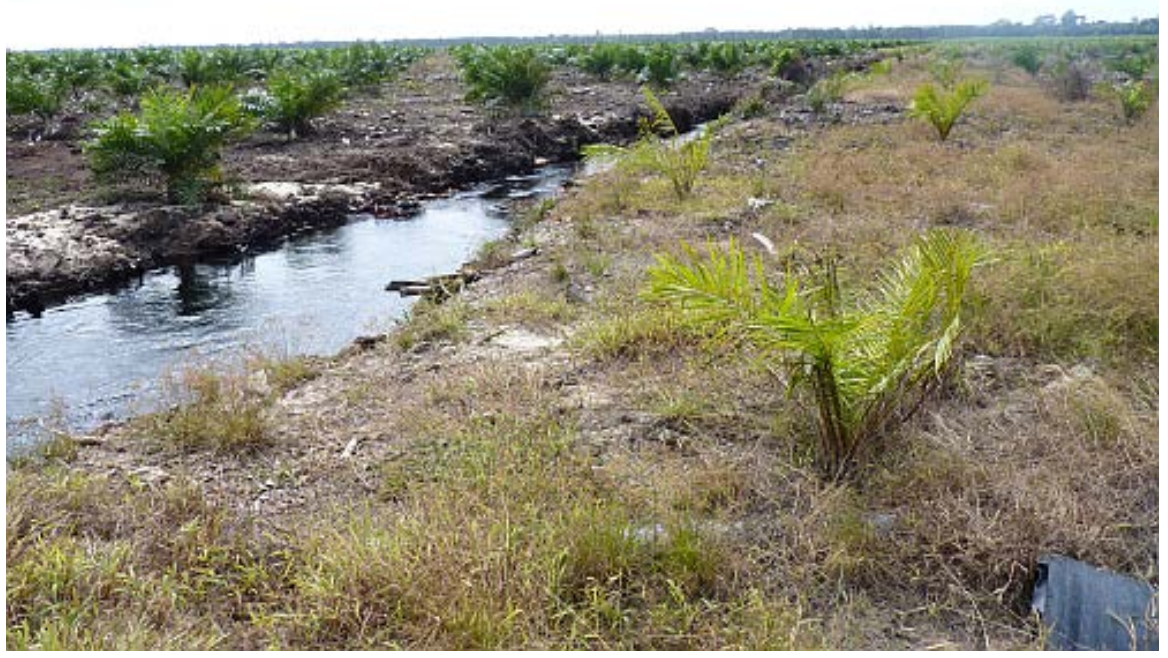

Figure 20. Difference between palms with (left) and without (right) OrganiGro treatment

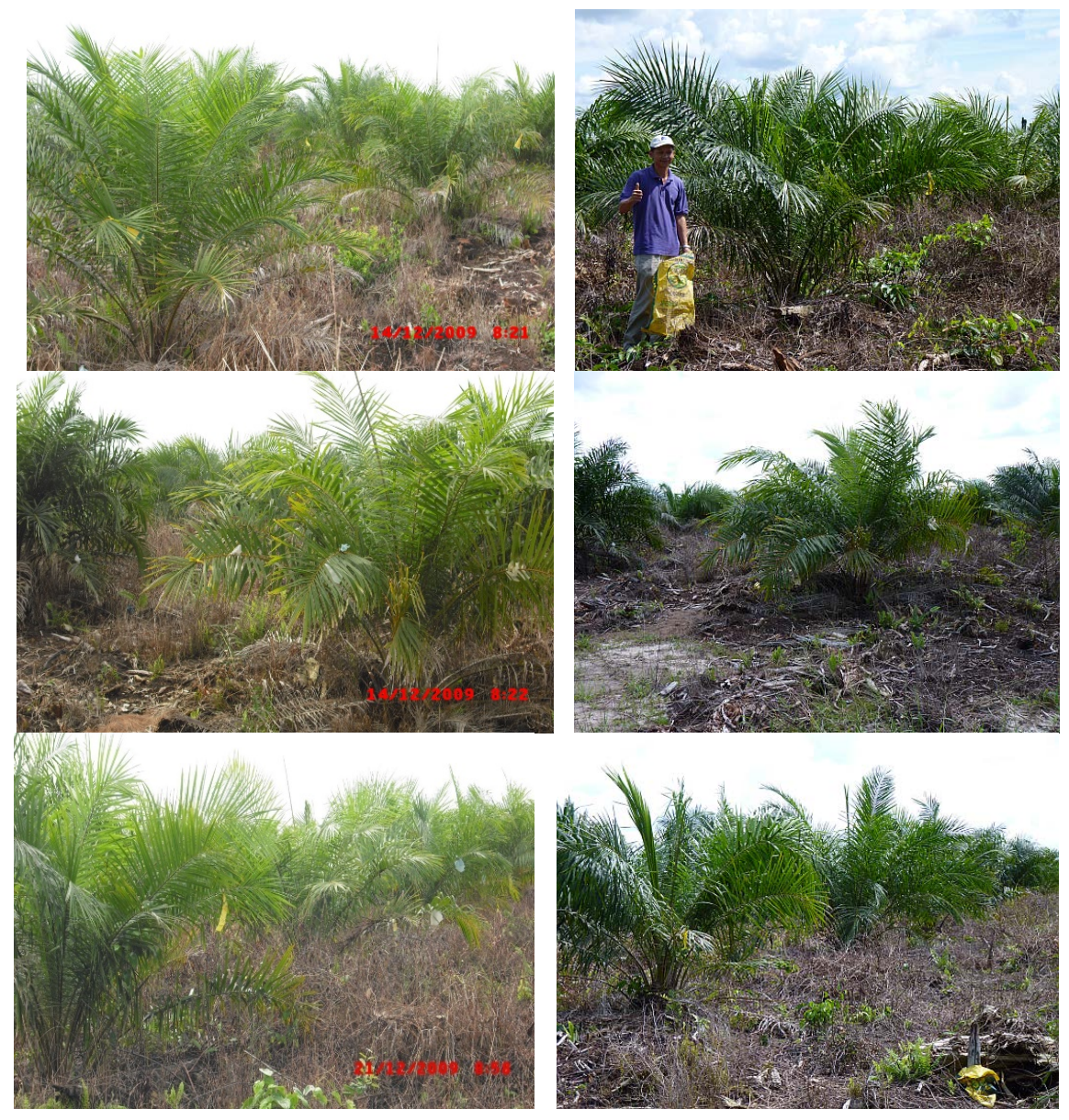

Figure 21. Palms before (left) and after one month of OrganiGro treatment (right). 
which led to stunted growth. This had a big impact on future yield. OrganiGro encouraged good agricultural practices in plantations by promoting usage of bio-organic products for soil treatment. In deep peat areas similar to this plantation, these practices were even more significant for getting fresh fruit bunch (FFB) yield in the future by minimising the effects of biotic and abiotic stress.

\subsection{OrganiGro's Applications in the Tobacco Industry}

\section{Case Study 7: Ismail Daud, Pantai Irama, Kelantan}

The late Ismail Daud started using OrganiGro in 2002 and immediately saw results. The usual harvest was around $800 \mathrm{~kg}$ of leaves per hectare per season, which was not a good average yield. This could be attributed to a disease called Fursarium wilt. The farmers doubled their yield to $1700 \mathrm{~kg}$ per hectare after using OrganiGro. Ismail was comparing his plot (with OrganiGro) and his neighbour's (without OrganiGro) in Figure 22.

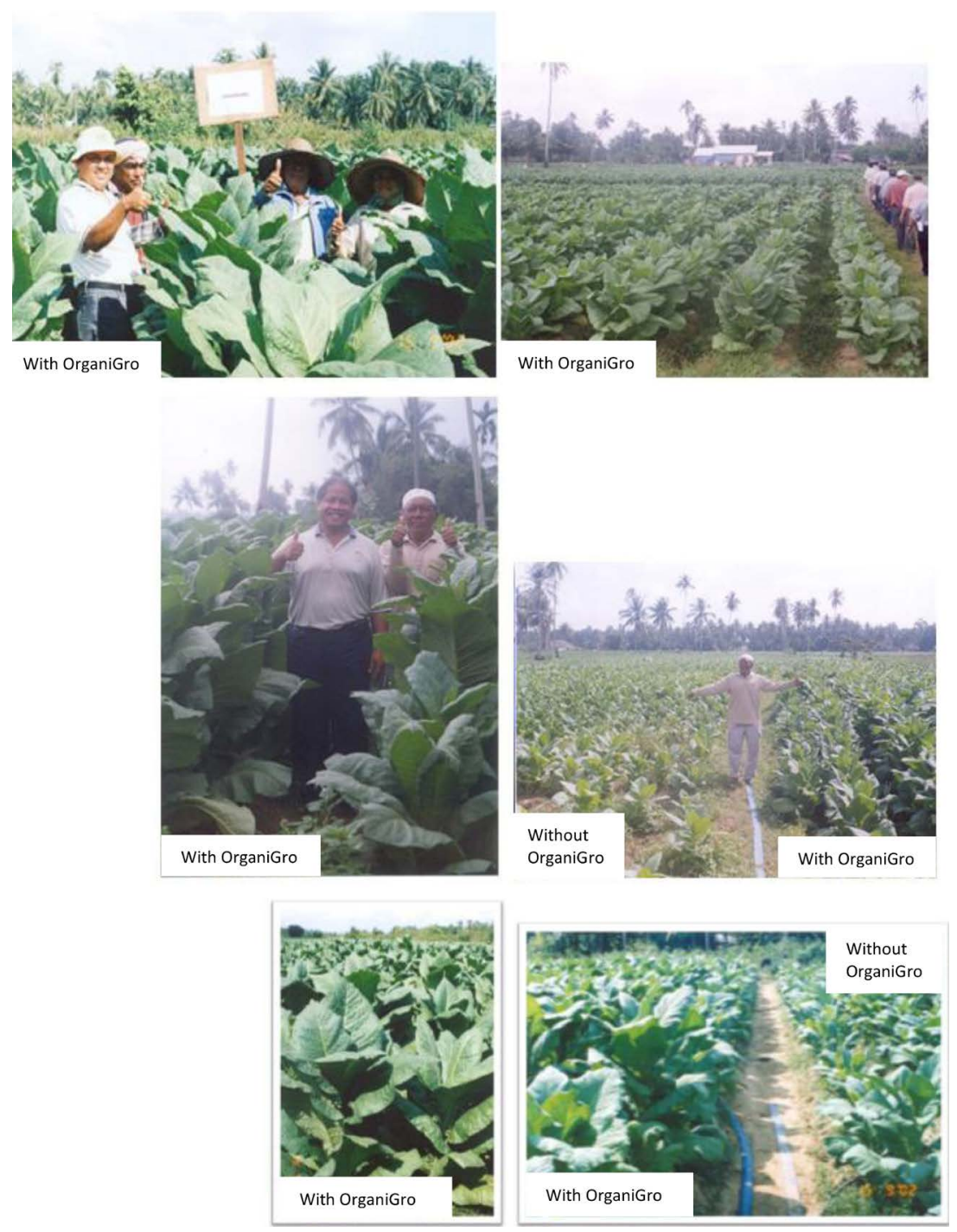

Figure 22. Comparison of tobacco plots with and without OrganiGro treatment. 


\section{Case Study 8: Azahari bin Ali, Kampong Kelarek, Kelantan}

Azahari bin Ali was the headman of Kampong Kelarek. He was asked to leave a plot of his tobacco plant untreated with OrganiGro. The untreated plot (right, Figure 23) succumbed to Fursarium wilt attack and was completely damaged, while the treated plot (left, Figure 23) beside it was not affected at all. The microbes in OrganiGro fully occupied the rhizosphere of the tobacco plant and protected it from pathogen attack.

This demonstration was a turning point for OrganiGro in the tobacco industry. It opened the door for OrganiGro to be supplied to most farmers under British American Tobacco and Japanese Tobacco International in Kelantan.

In the years when the Malaysian government was reducing tobacco cultivation under the pressure of anti-tobacco lobbying, and encouraging farmers to plant alternative crops instead, the government only subsidised one tobacco season as opposed to two seasons per year earlier. Since OrganiGro could double the farmers' yield, they retained their yearly income even though they can now only plant tobacco for one season, and made extra income from planting watermelon in the next season.

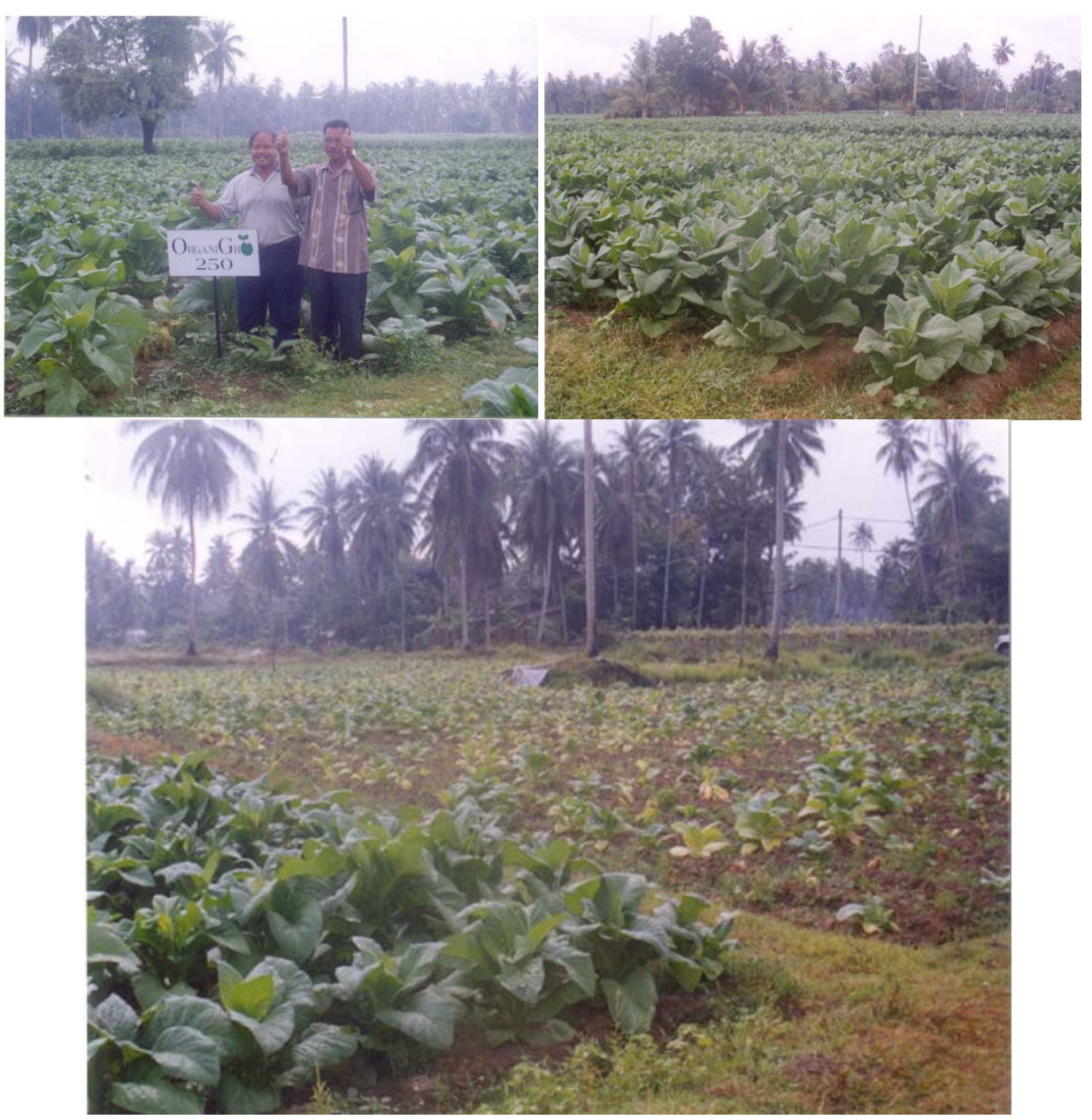

Figure 23. Comparing tobacco plots with (left) and without (right) OrganiGro treatment. 


\section{Summary of OrganiGro's Microbial Function}

By inoculating soils and plants with beneficial microorganisms, a more favourable microbiological environment for plant growth was created. The functions of the effective microbes present in OrganiGro are summarised as follows:

a) Fixation of atmospheric nitrogen

b) Decomposition of organic matter and residues

c) Suppression of soil borne pathogens

d) Recycling and increasing availability of plant nutrients

e) Degradation of toxicants including pesticides

f) Production of antibiotics and other bioactive compounds

g) Production of simple organic molecules for plant uptake

h) Complexation of heavy metals to limit plant uptake

i) Solubilisation of insoluble nutrient sources

j) Production of polysaccharides to improve soil

The beneficial influences of the OrganiGro mix of effective microbes in the soil to plant growth were that the yields and quality of crops were enhanced. The following were the benefits gained by crops observed after microbial action in the soil.

a) Promotion of germination, flowering, fruiting and ripening in plants

b) Improvement of physical, chemical and biological environments of the soil and suppression of soil borne pathogens and pests

c) Enhancement of the photosynthetic capacity of crops

d) Better germination and plant establishment

e) Increased efficacy of organic matter as fertilisers

\subsection{OrganiGro Organic Soil Ameliorant and Its Hidden Values}

OrganiGro organic soil ameliorant did not simply refer to plain compost or the decomposed organic matter. It was a finished product which was scientifically blended to consist of biodegradable materials of plant origin mixed with trace elements and often minerals in chelated form so that the soil became a source of nutritionally balanced plant food, fortified with plant growth promotants, enzymes, vitamins, probiotics, organic and amino acids, and finally inoculated with the beneficial microorganisms for nutrient fixations and increased assimilation by plants. Functional compounds such as chelated agents, emulsifiers and surfactants were also added to ensure product quality and enhanced nutrient assimilation rate.

The developed technology when applied in the production of an organic soil ameliorant ensured a finished product with the following characteristics:

1) Excellent soil conditioner making the soil more friable. In other words, it provided the soil good tilth;

2) Enhanced the cation exchange capacity (CEC) or nutrient binding capacity of the soil;

3) Enhanced the growth of beneficial soil microorganisms that helped to re- 
lease elements and make them more available for plant use;

4) Strengthened plant stem and leaf structure due to the presence of silica from rice husk. Thus, for cereals such as rice, wheat, barley etc. the increase in stem sturdiness encouraged more grain production;

5) Enhanced nitrogen fixation as well as that of other major elements. This translated into substantial savings on commercial fertilisers;

6) Encouraged the formation of growth promoting substances advantageous to plant growth;

7) Source of organic acids that could improve the assimilability of soil minerals by plants;

8) Beneficially affected the chemistry of inorganic fertilisers in the soil, minimising their degree of mineralisation;

9) Enhanced soil moisture retention by increasing the water holding capacity;

10) Minimised sharp fluctuations in soil temperature, thus minimising the stress in plants due to wide gaps in day and night time temperature;

11) Promoted a soil-balancing effect. The soil in which a plant grows must be in a balanced state, physically, chemically and biologically for maximum productivity.

\subsection{Summary of Advantages of OrganiGro over Other Soil Ameliorants}

The benefits that can be derived from OrganiGro have been discussed. In general terms the following features can be cited as to why the use of OrganiGro in soil must be encouraged either on its own, or together with inorganic fertilisers.

1) Cost saving. It was proven that OrganiGro offered the lowest application rate in the present organic market. Usage of OrganiGro with inorganic fertiliser resulted in better yield than that of chemical fertilisation alone. Silica reduced the amount of resources spent on pest and disease control and the improvement in soil structure brought about by super strain microbes resulted in more efficient nutrient uptake. Thus, the amount of inorganic fertiliser used could be reduced by up to $20 \%$ in the first year of using OrganiGro.

2) Ecological considerations. Chemical fertilisation resulted in depleted and acidic soils. Growth of beneficial organisms was adversely affected when soil turned acidic and biological activity slowed down. Biologically inactive soil decomposed organic matter much slower than biologically active soil. The conversion of nutrients into their assimilable form also slowed down when their bacteria population was reduced. However, when OrganiGro was used together with inorganic fertilisers, harmful effects of the chemicals were reduced, thus making the soil more fertile and biologically stable.

\section{Overall Conclusion and Recommendations for Further Work}

What is central to this paper is how the detailed nature of the soil itself, and in 
particular the fertility within it that is the "productive capital asset" highlighted in the title of the paper, and described in substantial detail in the first, scientific, half of the paper, is totally absent from the practitioner's understanding of the farming process of growing various different crops effectively "in" this stuff called "soil". Yet these self-same case studies demonstrate it to be a crippling blindness, leading to much lower yields, and far more plant sickness, than can easily be achieved with a good understanding of, and development of, this key productive asset. A right focus, in the first place, on what your greatest productive asset is and how it works, and the determined development of a clear understanding of the science underlying what makes it productive, is fundamental to the development of good farming practice and the only question that matters is, how can this understanding be gained, taught and applied-and prized-as a professional skill, as fast as possible?

More extensive trials, along with the underpinning scientific work, need to be done and they need to be extended to include the associated topics, touched on but not discussed in detail in this paper, of co-cropping. For instance during the early growth stage of oil palms, Centrosema pubescens, which is a leguminous cover crop, is normally grown to stop soil erosion, protect the soil from direct exposure to the sun, and provide nitrogen to the soil; it becomes green manure when it dies down later. As oil palms mature, watermelon and groundnuts can be inter-cropped with the palm trees. The remnants after harvesting can be dug in to directly improve soil fertility as "green manure", to enhance the richness and productivity of the figure-of-eight fertility cycle. These are issues of strategic importance when "sustainability" is becoming the central issue concerning the future of humanity.

\section{Acknowledgements}

The authors thank YAM Dato' Seri Syed Razlan Syed Putra Jamalullail and Khirel Anuar Ismail from OrganiGro Sdn. Bhd. for contributing their invaluable practitioners' insights, fieldwork data and pearls of wisdom in soil fertility. This work would not have been complete without their input.

\section{Conflicts of Interest}

The authors declare no conflicts of interest regarding the publication of this paper.

\section{References}

[1] What Are the Major Components of Soil? Socratic Q\&A: Environmental Science. https://socratic.org/questions/what-are-the-major-components-of-soil

[2] van Loon, G.W. and Duffy, S.J. (2017) Environmental Chemistry: A Global Perspective. Fourth Edition, Oxford University Press, Oxford.

[3] USDA. Soil Respiration: Soil Quality Kit for Educators. United State Department of Agriculture Natural Resources Conservation Service. 
https://www.nrcs.usda.gov/Internet/FSE_DOCUMENTS/nrcs142p2_053267.pdf

[4] Bonneval, K. Listen to the Soil.

https://www.karinebonneval.com/eng/projets/ecouter-la-terre-10

[5] Biovision Foundation. Sounding Soil. Biovision. https://www.biovision.ch/en/projects/switzerland/sounding-soil

[6] Smithsonian Science Education Centre. What Is Photosynthesis. https://ssec.si.edu/stemvisions-blog/what-photosynthesis

[7] Mahmud, K., Makaju, S., Ibrahim, R. and Missaoui, A. (2020) Current Progress in Nitrogen Fixing Plants and Microbiome Research. Plants, 9, 97. https://doi.org/10.3390/plants9010097

[8] Wagner, S.C. (2011) Biological Nitrogen Fixation. Nature Education Knowledge, 3, 15.

[9] The Editors of Encyclopaedia Britannica. Nitrogen-Fixing Bacteria. Britannica. Encyclopaedia Britannica. https://www.britannica.com/science/nitrogen-fixing-bacteria

[10] Jnawal, A.D., Ojha, R.B. and Marahatta, S. (2015) Role of Azotobacter in Soil Fertility and Sustainability-A Review. Advances in Plants \& Agriculture Research, 2, 250-253.

[11] Ding, Y., Wang, J., Liu, Y. and Chen, S. (2005) Isolation and Identification of Nitrogen-Fixing Bacilli from Plant Rhizospheres in Beijing Region. Journal of Applied Microbiology, 99, 1271-1281.

[12] Oregon State University (2020) List and Discuss Factors That Affect the Quantity of Nitrogen Fixed. Forage Information System, Oregon State University, Department of Crop and Soil Science.

https://forages.oregonstate.edu/nfgc/eo/onlineforagecurriculum/instructormaterials /availabletopics/nitrogenfixation/quantity

[13] Biello, D. (2007) Nitrogen Fixation: Scientists Solve the Mystery of Life-Sustaining Nutrient Cycle. Scientific American.

[14] Alexander, M. (1977) Introduction to Soil Microbiology. John Wiley, New York.

[15] Swanepoel, P.A., Botha, P.R., Truter, W.F. and Surridge-Talbot, A.K.J. (2011) The Effect of Soil Carbon on Symbiotic Nitrogen Fixation and Symbiotic Rhizobium Populations in Soil with Trifolium repens as Hostplant. African Journal of Range and Forage Science, 28, 121-127. https://doi.org/10.2989/10220119.2011.642096

[16] Ninawe, A. and Paulraj, R. (1997) Effect of pH on Growth and Nitrogen Fixation of Azotobacter Spp. Journal of Aquaculture, 5, 23-29.

[17] Becking, J.H. (1961) Studies on Nitrogen-Fixing Bacteria of the Genus Beijerinckia: I. Geographical and Ecological Distribution in Soils. Plant and Soil, 14, 49-81. https://doi.org/10.1007/BF01343769

[18] Roger, P.A. and Reynaud, P.A. (1982) Free-Living Blue-Green Algae in Tropical Soils. In: Dummergues, Y.R. and Diem, H.G., Eds., Microbiology of Tropical Soils and Plant Productivity, Martinus Nijhoff/Dr. W. Junk Publishers, The Hague/Boston/London, 147-168. https://doi.org/10.1007/978-94-009-7529-3_5

[19] Rousk, K., Sorensen, P.L. and Michelsen, A. (2018) What Drives Biological Nitrogen Fixation in High Arctic Tundra: Moisture or Temperature? Ecosphere, 9, e02117.

[20] Texas A\&M University (2009) Earth-Kind Landscaping. Aggie Horticulture. https://aggie-horticulture.tamu.edu/earthkind/landscape/dont-bag-it/chapter-1-thedecomposition-process 
[21] Walpola, B.C. and Yoon, M. (2012) Prospectus of Phosphate Solubilizing Microorganisms and Phosphorus Availability in Agricultural Soils: A Review. African Journal of Microbiology Research, 6, 6600-6605. https://doi.org/10.5897/AJMR12.889

[22] Rodríguez, H. and Fraga, R. (1999) Phosphate Solubilizing Bacteria and Their Role in Plant Growth Promotion. Biotechnology Advances, 17, 319-339. https://doi.org/10.1016/S0734-9750(99)00014-2

[23] Hina, M., Vandana, Sandeep, S. and Renu, P. (2018) Phosphorus Nutrition: Plant Growth in Response to Deficiency and Excess. In: Hasanuzzaman, M., et al., Eds., Plant Nutrients and Abiotic Stress Tolerance, Springer Nature, Singapore, 171-190. https://doi.org/10.1007/978-981-10-9044-8_7

[24] Sindhu, S.S., Parmar, P. and Phour, M. (2014) Nutrient Cycling: Potassium Solubilization by Microorganisms and Improvement of Crop Growth. In: Nagina, S. and Parmar, A., Eds., Geomicrobiology and Biogeochemistry, Springer, Berlin, 175-196. https://doi.org/10.1007/978-3-642-41837-2_10

[25] Bhattacharyya, P.N. and Jha, D.K. (2012) Plant Growth-Promoting Rhizobacteria (PGPR): Emergence in Agriculture. World Journal of Microbiology and Biotechnology, 28, 1327-1350. https://doi.org/10.1007/s11274-011-0979-9

[26] Kalayu, G. (2019) Phosphate Solubilizing Microorganisms: Promising Approach as Biofertilizers. International Journal of Agronomy, 2019, Article ID: 4917256. https://doi.org/10.1155/2019/4917256

[27] Alori, E., Fawole, O. and Afolayan, A. (2012) Characterization of Arbuscular Mycorrhizal Spores Isolated from Southern Guinea Savanna of Nigeria. The Journal of Agricultural Science, 4, 13-19. https://doi.org/10.5539/jas.v4n7p13

[28] Babalola, O.O. and Glick, B.R. (2012) The Use of Microbial Inoculants in African Agriculture: Current Practice and Future Prospects. The Journal of Food, Agriculture and Environment, 10, 540-549.

[29] Kumar, S., Bauddh, K., Barman, S.C. and Singh, R.P. (2014) Amendments of Microbial Bio Fertilizers and Organic Substances Reduces Requirement of Urea and DAP with Enhanced Nutrient Availability and Productivity of Wheat (Triticum aestivum L.). Ecological Engineering, 71, 432-437.

https://doi.org/10.1016/j.ecoleng.2014.07.007

[30] Jahan, M., Mahallati, M.N., Amiri, M.B. and Ehyayi, H.R. (2013) Radiation Absorption and Use Efficiency of Sesame as Affected by Biofertilizers Inoculation in a Low Input Cropping System. Industrial Crops and Products, 43, 606-611. https://doi.org/10.1016/j.indcrop.2012.08.012

[31] David, P., Raj, R.S., Linda, R. and Rhema, S.B. (2014) Molecular Characterization of Phosphate Solubilizing Bacteria (PSB) and Plant Growth Promoting Rhizobacteria (PGPR) from Pristine Soils. International Journal of Innovative Science Engineering and Technology, 1, 317-324.

[32] Mamta, R.P., Pathania, V., Gulati, A., Singh, B., Bhanwra, R.K. and Tewari, R. (2010) Stimulatory Effect of Phosphate-Solubilizing Bacteria on Plant Growth, Stevioside and Rebaudioside-A Contents of Stevia rebaudiana Bertoni. Applied Soil Ecology, 46, 222-229. https://doi.org/10.1016/j.apsoil.2010.08.008

[33] Zhao, K., Penttinen, P., Zhang, X., Ao, X., Liu, M., Yu, X. and Chen, Q. (2014) Maize Rhizosphere in Sichuan, China, Hosts Plant Growth Promoting Burkholderia Cepacia with Phosphate Solubilizing and Antifungal Abilities. Microbiological Research, 169, 76-82. https://doi.org/10.1016/j.micres.2013.07.003

[34] Istina, I.N., et al. (2015) Phosphate-Solubilizing Microbe from Saprists Peat Soil and 
Their Potency to Enhance Oil Palm Growth and P Uptake. Procedia Food Science, 3, 426-435. https://doi.org/10.1016/j.profoo.2015.01.047

[35] Chakraborty, U., Chakraborty, B.N., Basnet, M. and Chakraborty, A.P. (2009) Evaluation of Ochrobactrum Anthropi TRS-2 and Its Talc Based Formulation for Enhancement of Growth of Tea Plants and Management of Brown Root Rot Disease. Journal of Applied Microbiology, 107, 625-634. https://doi.org/10.1111/j.1365-2672.2009.04242.x

[36] Zhu, F., Qu, L., Hong, X. and Sun, X. (2011) Isolation and Characterization of a Phosphate-Solubilizing Halophilic Bacterium Kushneria sp. YCWA18 from Daqiao Saltern on the Coast of Yellow Sea of China. Evidence-Based Complementary and Alternative Medicine, 2011, Article ID: 615032. https://doi.org/10.1155/2011/615032

[37] Fernández Bidondo, L., Silvani, V., Colombo, Pérgola, M., Bompadre, J. and Godeas, A. (2011) Pre-Symbiotic and Symbiotic Interactions between Glomus intraradices and Two Paenibacillus Species Isolated from AM Propagules. In Vitro and in Vivo Assays with Soybean (AG043RG) as Plant Host. Soil Biology and Biochemistry, 43, 1866-1872. https://doi.org/10.1016/j.soilbio.2011.05.004

[38] Tajini, F., Trabelsi, M. and Drevon, J.J. (2012) Combined Inoculation with Glomus intraradices and Rhizobium Tropici CIAT899 Increases Phosphorus Use Efficiency for Symbiotic Nitrogen Fixation in Common Bean (Phaseolus vulgaris L.). Saudi Journal of Biological Sciences, 19, 157-163. https://doi.org/10.1016/j.sjbs.2011.11.003

[39] Postma, J., Nijhuis, E.H. and Someus, E. (2010) Selection of Phosphorus Solubilizing Bacteria with Biocontrol Potential for Growth in Phosphorus Rich Animal Bone Charcoal. Applied Soil Ecology, 46, 464-469.

https://doi.org/10.1016/j.apsoil.2010.08.016

[40] Srinivasan, R., Yandigeri, M.S., Kashyap, S. and Alagawadi, A.R. (2012) Effect of Salt on Survival and P-Solubilization Potential of Phosphate Solubilizing Microorganisms from Salt Affected Soils. Saudi Journal of Biological Sciences, 4, 427-434. https://doi.org/10.1016/j.sjbs.2012.05.004

[41] Sharma, S.B., Sayyed, R.Z., Trivedi, M.H. and Gobi, T.A. (2013) Phosphate Solubilizing Microbes: Sustainable Approach for Managing Phosphorus Deficiency in Agricultural Soils. Springerplus, 2, 587. https://doi.org/10.1186/2193-1801-2-587

[42] Alor, E.T., Glick, B.R. and Babalola, O.O. (2017) Microbial Phosphorus Solubilization and Its Potential for Use in Sustainable Agriculture. Frontiers in Microbiology, 8, 971. https://doi.org/10.3389/fmicb.2017.00971

[43] Maranguit, D. (2017) Effects of Flooding on Phosphorus and Iron Mobilization in Highly Weathered Soils: Short-Term Effects and Mechanisms. 19th EGU General Assembly, EGU2017, Proceedings from the Conference, Vienna, 23-28 April 2017, 787.

[44] Zörb, C., Senbayram, M. and Peiter, E. (2014) Potassium in Agriculture-Status and Perspectives. Journal of Plant Physiology, 171, 656-669. https://doi.org/10.1016/j.jplph.2013.08.008

[45] Amtmann, A., Troufflard, S. and Armengaud, P. (2008) The Effect of Potassium Nutrition on Pest and Disease Resistance in Plants. Physiologia Plantarum, 133, 682-691. https://doi.org/10.1111/j.1399-3054.2008.01075.x

[46] Pettigrew, W.T. (2008) Potassium Influences on Yield and Quality Production for Maize, Wheat, Soybean and Cotton. Physiologia Plantarum, 133, 670-681. 
https://doi.org/10.1111/j.1399-3054.2008.01073.x

[47] Havlin, J.L., Tisdale, S.L., Beaton, J.D. and Nelson, W.L. (2005) Soil Fertility and Fertilizer: An Introduction to Nutrient Management. Pearson Education, London.

[48] Etesami, H., Emami, S. and Alikhani, H.A. (2017) Potassium Solubilizing Bacteria (KSB): Mechanisms, Promotion of Plant Growth, and Future Prospects: A Review. Journal of Soil Science and Plant Nutrition, 17, 897-911. https://doi.org/10.4067/S0718-95162017000400005

[49] Ahmad, M., Nadeem, S.M., Naveed, M. and Zahir, Z.A. (2016) Potassium Solubilizing Microorganisms for Sustainable Agriculture. In: Maurya, B., Verma, J., Meena, R. and Meena, V., Eds., Potassium-Solubilizing Bacteria and Their Application in Agriculture, Springer, New Delhi, 293-313.

https://doi.org/10.1007/978-81-322-2776-2_21

[50] Parmar, P. and Sindhu, S.S. (2013) Potassium Solubilization by Rhizosphere Bacteria: Influence of Nutritional and Environmental Conditions. Journal of Microbiology Research, 3, 25-31.

[51] Dar, G.H. (2010) Soil Microbiology and Biochemistry. New India Publishing Agency NIPA.

[52] Pratama, D. and Anas, I. (2016) Ability of Potassium-Solubilissing Microbes to Solubilise Feldspar and Their Effects on Sorghum Growth. Malaysian Journal of Soil Science, 20, 163-175.

[53] Chaney, R.L., Broadhurst, C.L. and Centofanti, T. (2010) Phytoremediation of Soil Trace Elements. In: Hooda, P.S., Ed., Trace Elements in Soils, Wiley, Hoboken, 311-352. https://doi.org/10.1002/9781444319477.ch14

[54] Miransari, M. (2013) Soil Microbes and the Availability of Soil Nutrients. Acta Physiologiae Plantarum, 35, 3075-3084. https://doi.org/10.1007/s11738-013-1338-2

[55] Sherman, G.D. (1957) Year Book of Agriculture. U.S. Govt. Print. Off., Washington DC, 135-139.

[56] Hong, E., Ketterings, Q. and McBride, M. (2010) Agronomy Fact Sheet Series-Manganese. Nutrient Management Spear Programme. http://nmsp.cals.cornell.edu/publications/factsheets/factsheet49.pdf

[57] Rengel, Z. (1997) Root Exudation and Microflora Populations Inrhizosphere of Crop Genotypes Differing in Tolerance to Micro-Nutrient Deficiency. Plant Soil, 196, 255-260.

[58] Timonin, M.I. (1946) Microflora of the Rhizosphere in Relation to the Manganese-Deficiency Disease of Oats. Soil Science Society of America, Proceedings, 11, 284-292. https://doi.org/10.2136/sssaj1947.036159950011000C0054x

[59] Rengel, Z., Gutteridge, R., Hirsch, P. and Hornby, D. (1996) Plant Genotype, Micronutrient Fertilisation and Take-All Infection Influence Bacterial Populations in the Rhizosphere of Wheat. Plant Soil, 183, 269-277. https://doi.org/10.1007/BF00011442

[60] Goteti, P.K., Emmanuel, L.D.A., Desai, S. and Shaik, M.H.A. (2013) Prospective Zinc Solubilising Bacteria for Enhanced Nutrient Uptake and Growth Promotion in Maize (Zea mays L.). International Journal of Microbiology, 2013, Article ID: 869697. https://doi.org/10.1155/2013/869697

[61] Kamran, S., Shahid, I., Deeba, B.N., Rizwan, M., Malik, K.A. and Mehnaz, S. (2017) Contribution of Zinc Solubilizing Bacteria in Growth Promotion and Zinc Content of Wheat. Frontiers in Microbiology, 8, 2593.

https://doi.org/10.3389/fmicb.2017.02593 
[62] Cakmak, I. (2008) Enrichment of Cereal Grains with Zinc: Agronomic or Genetic Biofortification? Plant and Soil, 302, 1-17. https://doi.org/10.1007/s11104-007-9466-3

[63] Saravanan, V.S., Subramoniam, S.R. and Raj, S.A. (2004) Assessing in Vitro Solubilization Potential of Different Zinc Solubilizing Bacterial (ZSB) Isolates. Brazilian Journal of Microbiology, 35, 121-125. https://doi.org/10.1590/S1517-83822004000100020

[64] Rattan, R.K. and Shukla, L.M. (1991) Influence of Different Zinc Carriers on the Utilization of Micronutrients by Rice. Journal of the Indian Society of Soil Science, 39, 808-810. https://doi.org/10.1038/ki.1991.101

[65] Crane, F.L., Sun, I.L. and Clark, M.G. (1985) Transplasma-Membrane Redox Systems in Growth and Development. Biochimica et Biophysica Acta, 811, 233-264. https://doi.org/10.1016/0304-4173(85)90013-8

[66] Hughes, M.N. and Poole, R.K. (1991) Metal Speciation and Microbial Growth-The Hard (and Soft) Facts. Journal of General Microbiology, 137, 725-734. https://doi.org/10.1099/00221287-137-4-725

[67] Wakatsuki, T. (1995) Metal Oxidoreduction by Microbial Cells. Journal of Industrial Microbiology, 14, 169-177. https://doi.org/10.1007/BF01569900

[68] Saravanan, V.S., Kumar, M.R. and Sa, T.M. (2011) Microbial Zinc Solubilization and Their Role on Plants. In: Maheshwari, D.K., Ed., Bacteria in Agrobiology: Plant Nutrient Management, Springer, Berlin, 47-63.

https://doi.org/10.1007/978-3-642-21061-7_3

[69] Bloodnick (2018) Role of Copper in Plant Culture. PROMIX. Premier Horticulture Ltd.

https://www.pthorticulture.com/en/training-center/role-of-copper-in-plant-culture

[70] Kabirinejad, S., Kalbasi, M., Khoshgoftarmanesh, A.H., Hoodaji, M. and Afyuni, M. (2014) Chemical Forms and Phytoavailability of Copper in Soil as Affected by Crop Residues Incorporation. American Journal of Analytical Chemistry, 5, 604-612.

[71] Maluckov, B.S. (2017) The Catalytic Role of Acidithiobacillus ferrooxidans for Metals Extraction from Mining-Metallurgical Resource. Biodiversity International Journal, 1, 109-119. https://doi.org/10.15406/bij.2017.01.00017

[72] Imai, K.H., Sakaguchi, H., Sugio, T., Tano, T., Imai, K., Sakaguchi, H., Sugio, T. and Tano, T. (1973) On the Mechanism of Chalcocite Oxidation by Thiobacillus ferrooxidans. Journal of Fermentation Technology, 51, 865-870.

[73] (2010) Pleasant, Barbara. Systemic Pesticides: Chemicals You Can't Wash Off. Mother Earth News.

https://www.motherearthnews.com/nature-and-environment/environmental-policy /systemic-pesticides-zmaz10onzraw

[74] Tibbitts, S.A. (2016) Methods for Analyzing Silica Induced Effects: Trichome Structure and Leaf Desiccation Rate.

[75] Massey, F.P. and Hartley, S.E. (2008) Physical Defences Wear You Down: Progressive and Irreversible Impacts of Silica on Insect Herbivores. Journal of Animal Ecology, 78, 281-291. 